\title{
A FILOSOFIA DA LINGUAGEM ORDINÁRIA E A (INESCAPÁVEL) INDETERMINAÇÃO DO DIREITO
}

\author{
IGOR RAATZ ${ }^{\dagger}$ \\ WILLIAM GALLE DIETRICH ${ }^{\dagger \dagger}$ \\ GILBERTO MORBACH ${ }^{+++}$
}

RESUMO: Diante (i) da concepção de que o ôntico não é capaz de esgotar os sentidos e, portanto, que a lei não contém a completude do Direito, e, ao mesmo tempo, (ii) da auto-evidente relação entre Direito, linguagem e interpretação, vemos, contemporaneamente, dois tipos de resposta. De um lado, (i) discursos "neoconstitucionalistas" reivindicando, com ares de novidade, uma superação de um positivismo clássico, exegético, em que o juiz seria mera bouche de la loi; de outro, buscando remediar os problemas suscitados pelo discurso anterior, (ii) juristas, "vendendo" soluções milagrosas para enfrentar a questão da indeterminação do Direito, notadamente por meio de enunciados, precedentes, teses, súmulas, etc. $\mathrm{O}$ presente ensaio, portanto, a partir do "método" fenomenológico-hermenêutico, pretende demonstrar que as questões já há muito levantadas pela filosofia da linguagem ordinária antecede(ra)m qualquer perspectiva de teoria do Direito no sentido da impossibilidade de univocidade dos textos normativos $\mathrm{e}$, ao mesmo tempo, evidencia(va)m a impossibilidade de aprisionamento de sentido em proposições voltadas a oferecer respostas antes dos casos decidendos.

PAlAVRAS-ChAVE: Filosofia da linguagem; Neoconstitucionalismo; Textura aberta; Hermenêutica.

\footnotetext{
+ Pós-doutor, doutor e mestre em Direito pela Universidade do Vale do Rio dos Sinos UNISINOS. Professor do curso de graduação em Direito da Universidade FEEVALE Novo Hamburgo (RS). Professor em cursos de pós-graduação e graduação. Advogado. + Mestrando em Direito Público pela Universidade do Vale do Rio dos Sinos UNISINOS, como bolsista CAPES. Bacharel em Direito pela Universidade FEEVALE - Novo Hamburgo (RS).

${ }^{\text {t+t }}$ Acadêmico do curso de Direito da Universidade FEEVALE (RS).
} 
ABSTRACT: Considering that (i) the "ontic" could never exhaust every possible meaning and, therefore, that legal propositions cannot comprise the whole of the Law, and (ii) that the relations between Law, language, and interpretation are self-evident, we see two contemporary kinds of answers. First, neo-constitutionalist discourses claiming an overcoming of the old Montesquieu conceptions of bouche de la loi judges. In order to remediate the problems raised by such discourses, we see jurists attempting to solve interpretive "problems" through stare decisis, interpretive enunciations, legal statements, etc. The present essay, therefore, from a hermeneutical-phenomenological approach, aims to demonstrate that questions raised by the ordinary language philosophy precede jurisprudence, showing the impossibility of unequivocal normative texts and, at the same time, that it is impossible to anticipate meanings through propositions as answers even before the cases they are supposed to decide.

KEYWORDS: Ordinary language philosophy; Neoconstitutionalism; Open texture; Hermeneutics. 


\section{INTRODUÇÃO}

O Direito tem uma relação autoevidente com a interpretação. Qualquer que seja a concepção adotada, e mais, qualquer que seja o sistema jurídico em e com que se trabalhe, estar-se-á sempre lidando com a linguagem. É nesse sentido que surgem duas questões, aparentemente distintas, mas que complementam uma a outra: de um lado, (i) a percepção da impossibilidade de que o Direito tenha uma legislação completa, diante da qual o juiz comporte-se como mera bouche de la loi; de outro, (ii) o surgimento de "problemas" interpretativos, causados pela indeterminação do Direito. É nesse contexto que surgem, portanto, duas possíveis respostas conexas: de um lado, os discursos "neoconstitucionalistas", os quais, com ares de novidade, dizem que o juiz mero reprodutor de textos legais, fruto do exegetismo pós-Code Napoléon, já não existe mais, e, de outro, os discursos sustentadores da tese de que precedentes, súmulas, teses e enunciados sejam capazes de resolver os "problemas" decorrentes da superação do exegetismo, uniformizando a interpretação do Direito. O ponto, contudo, é que, enquanto a primeira resposta - qual seja, a de que o exegetismo foi superado - não é novidade, visto que a filosofia da linguagem já mostra isso há muito tempo (como ver-se-á ao longo deste ensaio), a segunda que defende que proposições resolvam problemas interpretativos almeja, paradoxalmente, escapar da inescapável indeterminação inerente à linguagem e, consequentemente, ao Direito. Dito de outro modo, a resposta "precedentalista" ao problema suscitado na primeira questão qual seja, do que fazer diante da inexorável indeterminação do Direito é construída como se fosse possível saltar para um outro nível linguístico, no qual textos normativos construídos por órgãos oficiais encarregados de realizar uma espécie de "interpretação autêntica" ${ }^{1}$ fossem dotados de qualidades especiais, sendo desprovidos, portanto, de qualquer espécie de indeterminação. Há, nessa construção teórica, como será melhor explicitado, uma inarredável contradição.

Para nossos objetivos, de desvelar isso tudo a partir da filosofia da linguagem ordinária, é necessário dar um passo atrás e entender os pressupostos que antecederam o giro ontológico-linguístico. Habermas chegou a dizer que a chamada "virada linguística" é efetuada tanto numa versão hermenêutica quanto numa versão analítica, as quais, para ele,

\footnotetext{
${ }^{1}$ A expressão "interpretação autêntica" é aqui utilizada no mesmo sentido em que, no medievo, se atribuía ao rei a última palavra interpretativa.
} 
relacionam-se entre $\mathrm{si}^{2}$. Isso porque tanto a virada linguística de matriz heideggeriana, quanto aquela que se decorre do segundo Wittgenstein, teriam operado uma mudança de paradigma - da filosofia da consciência para a filosofia da linguagem - a partir de uma igual primazia do a priori do sentido sobre a constatação dos fatos ${ }^{3}$. Antes disso, no entanto, é preciso ter presente que a invasão da filosofia pela linguagem inicia antes do próprio Heidegger e do segundo Wittgenstein. Há um caminho preteritamente percorrido, cuja compreensão será de grande valia para contrastá-los com o pensamento jurídico atual.

Antes, contudo, por compromisso teórico e rigor analítico, cumpre estabelecer, de antemão, os aspectos científicos deste ensaio. Teremos aqui, um objeto principal dúplice: pretendemos analisar, (i) de um lado, as relações entre Direito, linguagem e interpretação, sob os aportes da filosofia da linguagem ordinária, e, de outro, (ii) algumas das principais respostas de correntes contemporâneas no direito brasileiro diante do problema da indeterminação no Direito. De forma muito direta, é possível dizer que trabalhamos com uma hipótese muito clara e, como nosso objeto, também dúplice: a de que (i) as respostas, analisadas - e que preponderam na doutrina brasileira contemporânea - não se sustentam, uma vez que (ii) visam a responder a um problema de ontologia a partir de uma solução de caráter epistemológico. Dito de outro modo, a indeterminação é um fenômeno inerente ao Direito, razão pela qual sua tentativa de supressão por via legislativa e com a utilização de precedentes judiciais (melhor dizendo, mecanismos vinculantes) é uma empreitada fadada ao insucesso.

Para tanto, utilizou-se o método de abordagem fenomenológicohermenêutico. $\mathrm{O}$ método fenomenológico, dessa forma, surge não propriamente no sentido de descrever o que se manifesta, mas de

\footnotetext{
2 HABERMAS, Jürgen. Verdade e justificação. Ensaios filosóficos. Tradução: Milton Camargo Mota. São Paulo: Loyola, 2004, p. 64.

${ }^{3}$ HABERMAS, Jürgen. Verdade e justificação. Ensaios filosóficos. Tradução: Milton Camargo Mota. São Paulo: Loyola, 2004, p. 64. Ainda segundo Habermas, "no decorrer do século XIX generaliza-se a crítica contra a reificação e a funcionalização de formas de vida e de relacionamento, bem como contra a auto compreensão objetivista da ciência e da técnica. Estes motivos desencadeiam a crítica aos fundamentos de uma filosofia que comprime tudo nas relações sujeito-objeto. A mudança de paradigma da filosofia da consciência para a filosofia da linguagem situa-se precisamente neste contexto" (HABERMAS, Jürgen. Pensamento pós-metafísico: estudos filosóficos. Rio de Janeiro: Tempo brasileiro, 1990, p. 43).
} 
desvelar aquilo que por si vem oculto ${ }^{4}$. A ideia de método tem um sentido diferente quando se fala em metodologia de abordagem fenomenológicahermenêutica. Assim, para que se possa desconstruir e reconstruir a questão envolvendo o caráter indeterminado da linguagem e suas repercussões no Direito atual, é necessário “que se abale a rigidez e o endurecimento de uma tradição petrificada e se removam os entulhos acumulados" 5 . É o que Heidegger chama de destruição, que, por sua vez, não pode ser vista em um sentido negativo; ao contrário, ela deve definir e circunscrever a tradição em suas possibilidades positivas e "isso quer sempre dizer em seus limites, tais como se dão na colocação do questionamento e na delimitação, assim persignada, do campo de investigação possível" 6 . Disso se segue que esse "método" significa não apenas uma espécie de descrição daquilo que é dado, "mas inclui a supressão do encobrimento que não precisa consistir apenas em falsas construções teóricas"7.

Como métodos de procedimento, o presente ensaio vale-se dos métodos histórico e comparativo, relacionando a evolução da questão da linguagem em Gottlob Frege, Rudolf Carnap e Ludwig Wittgenstein, com as perspectivas que, no Direito, buscam lidar com o problema da sua indeterminação, problemática que somente pode ser, conforme busca o presente ensaio revelar, a partir do reconhecimento de que o fenômeno jurídico se encontra imerso em questões de natureza filosófica. A técnica de pesquisa utilizada foi a pesquisa bibliográfica-doutrinária, realizandose, para tanto, um robusto levantamento bibliográfico, seja no campo da filosofia, seja no campo do Direito.

\section{A QUESTÃO DA LINGUAGEM EM FREGE E CARNAP}

Como bem destacou Gadamer, desde Johann Gottfried Herder e Wilhelm von Humboldt, o pensamento moderno sobre a linguagem passou a ocupar-se de um interesse totalmente diferente, preocupandose em estudar como se desenvolve a naturalidade da linguagem humana

${ }^{4}$ STEIN, Ernildo. Aproximações sobre hermenêutica. Porto Alegre: EDIPUCRS, 1996, p. 24.

5 STEIN, Ernildo. Introdução ao pensamento de Martin Heidegger. Porto Alegre: EDIPUCRS, 2002, p. 55.

${ }^{6}$ HEIDEGGER, Martin. Ser e tempo. Parte I. 14 ed. Petrópolis: Editora Vozes, 2005, p. 51.

${ }^{7}$ GADAMER, Hans-George. Hermenêutica em retrospectiva. A virada hermenêutica. Vol. II. Tradução de Marco Antônio Casanova. Petrópolis: Vozes, 2007, p. 16. 
na amplitude de experiências dentro da diversidade da sua própria estruturação ${ }^{8}$. Juntamente com Johann Georg Hamann, Herder e Humboldt inauguram a virada linguística, sob duas frentes: em primeiro lugar, como consequência da superação da linguagem como instrumento ela passa a ser considerada elemento constitutivo do pensamento e do conhecimento, sendo considerada condição de possibilidade tanto da objetividade da experiência quanto da intersubjetividade da comunicação'; em segundo lugar, essa nova concepção da linguagem impõe uma descentralização da razão, de modo que, manifestando-se a linguagem sempre em línguas particulares e históricas, ela não permite uma separação estrita entre o transcendental e o empírico, entre o a priori e o a posteriori ${ }^{10}$.

Cristina Lafont visualiza duas dimensões na mudança de paradigma operada por Humboldt. Na dimensão cognitiva-semântica, a linguagem é vista como algo constitutivo da atividade de pensar, como condição de possibilidade dessa atividade. Na dimensão comunicativa-pragmática, o caráter constitutivo da linguagem é visto como resultado de uma atividade, no caso, a prática de falar (the praxis of speaking). Desse modo, a linguagem torna-se a garantidora da intersubjetividade da comunicação, a condição de possibilidade do entendimento entre os falantes ${ }^{11}$

Em Humboldt é possível visualizar uma antecipação da crítica à filosofia da consciência ${ }^{12}$. Na dimensão cognitiva-semântica, a linguagem como atividade revela-se no fato de que por meio dela criam-se novos conceitos, novos conteúdos por meio dos quais o mundo se faz acessível; na dimensão comunicativa-pragmática, a compreensão da atividade

\footnotetext{
8 GADAMER, Hans-Georg. Verdade e método. Tradução de Flávio Paulo Meurer; revisão da tradução de Enio Paulo Giachini. $7^{\mathfrak{a}}$ ed. Petrópolis, RJ: Vozes, Bragança Paulista, SP: Editora Universitária São Francisco, 2005, p. 566.

9 SEGATTO, Antonio Ianni. Apresentação do texto "Sobre pensamento e linguagem" de Wilhelm Von Humboldt. In: Trans/form/ação. Revista de filosofia. Universidade Estadual Paulista/UNESP. v. 32, n. 1, 2009, p. 193.

10 SEGATTO, Antonio Ianni. Apresentação do texto "Sobre pensamento e linguagem" de Wilhelm Von Humboldt. In: Trans/form/ação. Revista de filosofia. Universidade Estadual Paulista/UNESP. v. 32, n. 1, 2009, p. 194.

${ }^{11}$ LAFONT, Cristina. The linguistic turn in hermeneutic philosophy. Tradução de José Medina. Baskerville: Massachusetts Institute, 1999, p. 18.

${ }^{12}$ LAFONT, Cristina. The linguistic turn in hermeneutic philosophy. Tradução de José Medina. Baskerville: Massachusetts Institute, 1999, p. 19.
} 
revela-se na ideia de unificação por meio do diálogo, em que, no lugar do elemento transcendental da percepção, do "eu penso" kantiano, Humboldt coloca a intersubjetividade, representada pelas diferentes perspectivas dos participantes da comunicação, os quais objetivam alcançar um entendimento entre si sobre algo no mundo ${ }^{13}$.

A importância de Humboldt é, sem dúvida, muito grande, na medida em que ele, de certo modo, inaugura o chamado giro linguístico. Gadamer chega a considerá-lo o criador da moderna filosofia da linguagem ${ }^{14}$, notadamente em razão de ter descoberto a concepção da linguagem como concepção de mundo ${ }^{15}$.

É evidente que uma abordagem do giro linguístico não se resume a um acontecimento isolado. Pelo contrário, abarca diversos momentos no pensamento filosófico que, por sua vez, irão repercutir diretamente no modo de tratar o fenômeno jurídico na presente investigação. Como diz Rojas, a revolução linguística "no se realizó de la noche a la mañana, sino

13 SEGATTO, Antonio Ianni. Apresentação do texto "Sobre pensamento e linguagem" de Wilhelm Von Humboldt. In: Trans/form/ação. Revista de filosofia. Universidade Estadual Paulista/UNESP. v. 32, n. 1, 2009, p. 195. Conforme Habermas, "do ponto de vista semântico, Humboldt procede a uma dupla distinção do conceito transcendental da espontaneidade da linguagem, espontaneidade 'formadora do mundo'. A linguagem desenvolve operações constitutivas não apenas no nível dos modelos de interpretação cultural, mas também no das práticas sociais. No aspecto cognitivamente relevante, a linguagem articula uma pré-compreensão do mundo como um todo, partilhada intersubjetivamente pela comunidade linguística. Essa visão de mundo serve como recurso para modelos de interpretação partilhados. Discretamente, ela volta o olhar para direções relevantes, forma prevenções e cria assim o pano de fundo ou a moldura não-problemática para interpretações possíveis dos eventos intramundanos. Ao mesmo tempo, no aspecto relevante para a prática, a linguagem molda o caráter e a forma de vida de uma nação. Esse mundo da vida linguisticamente estruturado constitui o pano de fundo da prática cotidiana e marca o ponto de sutura onde a teoria social pode se anexar à teoria da linguagem" (HABERMAS, Jürgen. Verdade e justificação. Ensaios filosóficos. Tradução: Milton Camargo Mota. São Paulo: Loyola, 2004, pp. 73-74).

${ }^{14}$ GADAMER, Hans-Georg. Verdade e método. Tradução de Flávio Paulo Meurer; revisão da tradução de Enio Paulo Giachini. $7^{a}$ ed. Petrópolis, RJ: Vozes, Bragança Paulista, SP: Editora Universitária São Francisco, 2005, p. 566.

15 GADAMER, Hans-Georg. Verdade e método. Tradução de Flávio Paulo Meurer; revisão da tradução de Enio Paulo Giachini. $7^{a \mathfrak{a}}$ ed. Petrópolis, RJ: Vozes, Bragança Paulista, SP: Editora Universitária São Francisco, 2005, p. 571. 
a lo largo de cien años"16. Por isso, Lenio Streck afirma que não basta falar em "viragem linguística", pois ela não se compõe de uma simples guinada paradigmática, na medida em que é possível visualizá-la em diversas frentes ${ }^{17}$. Em sentido similar, Manfredo Oliveira desenvolve importantes considerações a respeito da sintaxe e da semântica da linguagem, como modo de preparar o terreno para aquilo que ele chama de "radicalização da reviravolta linguística"18.

Pode-se falar de uma teoria semântica tradicional, que, em sua forma mais simples, afirma que expressões linguísticas possuem apenas uma função semântica consistente em designar certas entidades à base de convenção ${ }^{19}$. Com a teoria semântica de Frege ${ }^{20}$ tem-se um passo adiante. Seu pensamento insere-se numa contraposição da lógica frente à

16 ROJAS OSORIO, Carlos. Genealogía del giro linguístico. Medellín: Editorial Universidad de Antioquia, 2006, p. 87.

17 STRECK, Lenio Luiz. Hermenêutica jurídica e(m) crise: uma exploração hermenêutica da construção do direito. $10^{\mathrm{a}}$ edição revista, atualizada e ampliada. Porto Alegre: Livraria do Advogado, 2011, p. 212.

18 OLIVEIRA, Manfredo Araújo de. Reviravolta linguístico-pragmática na filosofia contemporânea. São Paulo: Edições Loyola, 1996, p. 14.

${ }^{19}$ Trata-se, no caso, a semântica realista de F.v. Kutschera. A respeito, ver OLIVEIRA, Manfredo Araújo de. Reviravolta linguístico-pragmática na filosofia contemporânea. São Paulo: Edições Loyola, 1996, pp. 51-56.

${ }^{20}$ Segundo Manfredo de Oliveira, "Friedrich Ludwig Gottlob Frege nasceu no dia 8 de novembro de 1948, em Wismar, Alemanha. Estudou matemática, física, química e filosofia primeiramente na Universidade de Jena, depois em Göttingen, considerada, no tempo, o centro mundial da geometria, onde se doutorou em filosofia. Mais tarde foi professor de matemática em Jena. Embora Frege esteja hoje na origem de todo o movimento renovador da lógica, durante seu tempo ele foi praticamente desconhecido. Carnap, um dos grandes lógicos de nosso tempo, foi seu aluno e relata como, com mais dois outros alunos somente, estava presente às suas aulas, onde Frege apresentava, totalmente indiferente a seus alunos, suas descobertas a respeito dos problemas fundamentais que constituíram a paixão de sua vida: problemas da lógica e dos fundamentos da matemática". Hoje, no entanto, Frege é considerado o pai de todas as direções da filosofia analítica (OLIVEIRA, Manfredo Araújo de. Reviravolta linguístico-pragmática na filosofia contemporânea. São Paulo: Edições Loyola, 1996, p. 57). 
psicologia, numa dimensão de objetividade, portanto, contra o subjetivo da psicologia ${ }^{21}$.

O núcleo da filosofia da linguagem desenvolvida por Frege reside, essencialmente, nas discussões visando a clarificar, de um lado, as noções de objeto, conceito e função, e as relações que se dão entre eles, e, por outro, as noções de sentido e referência ${ }^{22}$. Para ele, objeto é qualquer coisa que possa ser designada por um nome próprio $^{23}$ e que possa exercer o papel de argumento ou valor de uma função. O objeto tanto pode ser um ente físico quanto lógico, como, por exemplo, um número. Desse modo, tudo quanto existe ou é uma função ou é um objeto. Linguisticamente, os objetos são designados por nomes próprios e as funções por expressões funcionais. As funções se hierarquizam em funções de primeira ordem quando seus argumentos são objetos - e de segunda ordem, quando seus argumentos são uma função de primeira ordem. As funções podem ser conceitos, quando possuem um único argumento cujo valor é o verdadeiro ou o falso ${ }^{24}$. Nisso já é possível verificar o pensamento lógico que perpassa as teorias de Frege.

A semântica de Frege tem seu cerne na distinção entre sentido e denotação (referência). Com efeito, o próprio nome tem duas funções

${ }^{21}$ OLIVEIRA, Manfredo Araújo de. Reviravolta linguístico-pragmática na filosofia contemporânea. São Paulo: Edições Loyola, 1996, p. 59. Conforme Manfredo de Oliveira, "suas distinções (características e qualidades, conceitos de primeiro e segundo níveis, subsunção de um objeto sob um conceito, subordinação de conceitos a outros conceitos e subsunção de um conceito sob um conceito de segundo nível etc) oram aquisições fundamentais para o esclarecimento da estrutura lógica de nosso pensamento" (OLIVEIRA, Manfredo Araújo de. Reviravolta linguístico-pragmática na filosofia contemporânea. São Paulo: Edições Loyola, 1996, p. 60).

${ }^{22}$ ALCOFORADO, Paulo. Introdução da obra. In: FREGE, Gottlob. Lógica e filosofia da linguagem. Seleção, introdução e notas de Paulo Alcoforado. $2^{\underline{a}}$ ed. São Paulo: Editora Universidade de São Paulo, 2009, p. 25.

${ }^{23}$ Importante que Frege entende por "sinal" e "nome" "qualquer designação que desempenhe o papel de um nome próprio, cuja referência seja um objeto determinado (esta palavra tomada na acepção mais ampla) (...) a designação de um objeto singular pode consistir em várias palavras ou sinais", sendo chamada de nome próprio toda designação desse gênero" (FREGE, Gottlob. Sobre o sentido e a referência (1893). In: Lógica e filosofia da linguagem. Seleção, introdução e notas de Paulo Alcoforado. $2^{\mathrm{a}}$ ed. São Paulo: Editora Universidade de São Paulo, 2009, pp. 131-132).

${ }^{24}$ ALCOFORADO, Paulo. Introdução da obra. In: FREGE, Gottlob. Lógica e filosofia da linguagem. Seleção, introdução e notas de Paulo Alcoforado. 2a ed. São Paulo: Editora Universidade de São Paulo, 2009, p. 26. 
semânticas, na medida em que ele denota um objeto e exprime um sentido. A linguagem humana, portanto, possui três dimensões: "a dimensão signativa (expressão linguística, sinais linguísticos), a dimensão objetiva (o objeto designado) e a dimensão significativa (a dimensão do sentido)"25. Desse modo, é plausível pensar que existe, unido a um sinal, além daquilo por ele designado, que pode ser chamado de sua referência, o sentido do sinal, em que está contido o modo de apresentação do objeto $^{26}$.

Um mesmo objeto pode, assim, ser denotado (referido) por mais de um sinal ou por diferentes sinais. O que se deve ter por certo é que toda expressão (nome próprio, termo conceitual, sentença) expressa um sentido e designa um referente. Desse modo, "os termos $2+2$ e $6-2$ se referem ou designam o mesmo referente, isto é, $4^{\prime \prime 27}$. Do mesmo modo, nos dois termos o objeto é designado de maneira diferente. O primeiro termo " $2+2$ " se refere ao número 4 através de uma adição, de um modo diferente, portanto, que o segundo termo " $6-2$ " que se refere ao mesmo objeto, já que neste isso é feito por uma subtração ${ }^{28}$. Frege dá ainda um outro exemplo, que costuma ser bastante mencionado por aqueles que se dispõem a analisar a sua obra. Enquanto o sentido de "Estrela da Tarde" e "Estrela da Manhã" seriam diferentes, a referência seria a mesma, pois ambas as expressões se referem ao planeta Vênus, embora, em cada uma delas, ele se manifeste de modo distinto: no primeiro caso, por brilhar ao anoitecer; no segundo, por desaparecer quando o sol surge ${ }^{29}$.

Frege deixa evidente que nem todo o nome possui um sentido perfeitamente determinado. Embora isso fosse desejável, ele reconhece como uma tarefa impossível de realizar na linguagem comum. Além

${ }^{25}$ OLIVEIRA, Manfredo Araújo de. Reviravolta linguístico-pragmática na filosofia contemporânea. São Paulo: Edições Loyola, 1996, p. 62.

${ }^{26}$ FREGE, Gottlob. Sobre o sentido e a referência (1893). In: Lógica e filosofia da linguagem. Seleção, introdução e notas de Paulo Alcoforado. $2^{\mathrm{a}}$ ed. São Paulo: Editora Universidade de São Paulo, 2009, p. 131.

${ }^{27}$ ALCOFORADO, Paulo. Introdução da obra. In: FREGE, Gottlob. Lógica e filosofia da linguagem. Seleção, introdução e notas de Paulo Alcoforado. $2^{\mathrm{a}}$ ed. São Paulo: Editora Universidade de São Paulo, 2009, p. 26.

${ }^{28}$ ALCOFORADO, Paulo. Introdução da obra. In: FREGE, Gottlob. Lógica e filosofia da linguagem. Seleção, introdução e notas de Paulo Alcoforado. $2^{\mathrm{a}}$ ed. São Paulo: Editora Universidade de São Paulo, 2009, p. 27.

${ }^{29}$ CORREA, Cristina Rosineiri Gonçalves Lopes. A semântica de Frege e a dinâmica da verdade na psicanálise. Rev. Estud. Lacan., 2009, vol. 2, n. 3, p. 02. 
disso, mesmo diante de nomes genuinamente próprios, as opiniões quanto ao sentido poderiam divergir e até turvar a referência ${ }^{30}$. Mas não é só isso. Frege, também reconhece que somente em um sistema perfeito de sinais a cada expressão corresponderia um sentido determinado, razão pela qual se deve ficar satisfeito "se a mesma palavra, no mesmo contexto, sempre tiver o mesmo sentido" 31 .

O ideal de exatidão e precisão do saber filosófico, já presente no pensamento de Frege, será revitalizado por Rudolf Carnap, o qual, nos anos 30, teria se tornado "um grande líder da assim chamada filosofia

${ }^{30}$ Segundo Frege, "poder-se-ia, por exemplo, tomar como seu sentido o seguinte: o discípulo de Platão e o mestre de Alexandre Magno. Quem fizer isso associará outro sentido à sentença 'Aristóteles nasceu em Estagira' do que alguém que tomar como sentido daquele nome: o mestre de Alexandre Magno que nasceu em Estagira. Enquanto a referência permanecer a mesma, tais oscilações de sentido podem ser toleradas, ainda que elas devam ser evitadas na estrutura teórica de uma ciência demonstrativa, não devem ter lugar numa linguagem perfeita" (FREGE, Gottlob. Sobre o sentido e a referência (1893). In: Lógica e filosofia da linguagem. Seleção, introdução e notas de Paulo Alcoforado. $2^{\underline{a}}$ ed. São Paulo: Editora Universidade de São Paulo, 2009, p. 132, nota 14).

31 FREGE, Gottlob. Sobre o sentido e a referência (1893). In: Lógica e filosofia da linguagem. Seleção, introdução e notas de Paulo Alcoforado. $2^{\mathrm{a}}$ ed. São Paulo: Editora Universidade de São Paulo, 2009, pp. 132-133. Também para as frases, Frege admite uma dupla função semântica, de modo que elas também têm denotação e sentido: "toda fase contém um pensamento, isto é, a proposição, o conteúdo ou, como se diz hoje, o conteúdo proposicional. Então, surge a pergunta: a proposição é a denotação ou o sentido da frase? Bem, se uma frase tem uma denotação, então esta não pode ser mudada quando na frase substituímos um nome por um outro que tem a mesma denotação, embora sentido diverso(...). A denotação de uma frase depende, portanto, unicamente, da denotação dos nomes próprios nela contidos e não de seu sentido (...). O que é a denotação de uma frase? É aquilo que permanece quando fazemos substituições transformadoras do sentido. Já que Frege entende a denotação como a relação a um objeto, então o que permanece nesse caso é, para usar uma expressão sua, o valor de verdade. É, como ele diz, a busca da verdade que nos faz passar do sentido para a denotação da frase. $O$ valor de verdade de uma frase é a circunstância de que ela é verdadeira ou falsa. Toda frase é, portanto, análoga a um nome próprio, isto é, denota um objeto. Só que, aqui, há apenas dois objetos: o verdadeiro e o falso. Em cada juízo se faz o passo do nível do sentido para o da denotação" (OLIVEIRA, Manfredo Araújo de. Reviravolta linguístico-pragmática na filosofia contemporânea. São Paulo: Edições Loyola, 1996, pp. 64-65). 
analítica"32. Na obra Sintaxe lógica da linguagem, Carnap procura mostrar a possibilidade de substituir todo o complexo emaranhado de problemas estudados na filosofia pela análise formal de certas linguagens formais, devidamente caracterizadas $^{33}$. Levando ao máximo a reviravolta linguística, a tarefa da filosofia vai, portanto, consistir na construção de linguagens formais artificiais, com a finalidade de reconstruir e provar a consistência lógica das teorias das ciências particulares, no que Carnap chega à conclusão de que não existe a verdadeira linguagem científica, mas apenas sistemas alternativos de tais linguagens ${ }^{34}$.

No intento de oferecer uma teoria geral dos sistemas formais, caberiam ao lógico três tarefas: (i) estudar as condições gerais sob as quais um sistema formal pode ser instituído, compreendendo-se aqui uma lista exaustiva dos símbolos da linguagem, regras de formação que determinem quais sequências de símbolos contam como proposições e regras de transformação direta, que determinam a estrutura dedutiva da linguagem, vale dizer, quais proposições podem ser formalmente deduzidas a partir de outras; (ii) desenvolver sistemas formais específicos, com diferentes estruturas, para os mais diversos fins; e (iii) desenvolver ferramentas e conceitos adequados ao estudo da estrutura dos diferentes sistemas formais ${ }^{35}$.

É com Carnap que pela primeira vez se apresenta a distinção entre metalinguagem e linguagem objetal, que, para o Direito, assumirá grande relevância notadamente na obra de Kelsen ${ }^{36}$. Assim, em primeiro lugar a linguagem objeto de investigação é chamada de linguagem objetal (object-

32 OLIVEIRA, Manfredo Araújo de. Reviravolta linguístico-pragmática na filosofia contemporânea. São Paulo: Edições Loyola, 1996, p. 71.

33 TRAJAN, Tiago. A sintaxe lógica da linguagem de Rudolf Carnap: uma análise do princípio de tolerância e da noção de analiticidade. Dissertação de mestrado. Programa de Pós-Graduação em Filosofia do Departamento de Filosofia da Faculdade de Filosofia, Letras e Ciências Humanas da Universidade de São Paulo - USP. São Paulo: USP, 2005, p. 11.

34 OLIVEIRA, Manfredo Araújo de. Reviravolta linguístico-pragmática na filosofia contemporânea. São Paulo: Edições Loyola, 1996, p. 74.

35 TRAJAN, Tiago. Entre Lógica e Epistemologia: Carnap, Quine e o significado do método formal. In: Cadernos de história e filosofia da ciência. Campinas, Série 3, v. 19, n. 2, p. 143-164, jul.-dez. 2009, pp. 149-150.

36 Para uma ampla discussão acerca da influência do empirismo lógico na obra do Jurista de Viena, ver STRECK, Lenio Luiz. Verdade e Consenso: constituição, hermenêutica e teorias discursivas. 6. ed. São Paulo: Saraiva, 2017, p. 39 e ss. 
language) e a linguagem na qual se fala a respeito das formas sintáticas da linguagem objeto é chamada de linguagem sintática (sintax-language $)^{37}$.

O pressuposto dessa fase de pensamento de Carnap, inclusive reconhecido em sua autobiografia, era de que, na linha das discussões

${ }^{37}$ CARNAP, Rudolf. Logical syntax of language. London: Routlegde, 2000, p. 04. Com efeito, "uma linguagem que é objeto de uma pesquisa qualquer se chama linguagem objeta. A linguagem usada para tratar da linguagem objetal é precisamente a metalinguagem. Nas pesquisas linguísticas empíricas, frequentemente essas linguagens são a mesma. Pode-se, por exemplo, em português escrever uma obra sobre a gramática portuguesa. No caso, porém, de uma pesquisa lógica, a linguagem simbólica que constitui o objeto dessa pesquisa não existe ainda, mas é produzida artificialmente. Ora, nesse caso, é a linguagem comum que funciona como metalinguagem, acrescida de alguns símbolos logicamente precisos. Na pesquisa sobre os fundamentos da lógica e da matemática, uma divisão clara e precisa desses dois níveis da linguagem é de enorme importância para evitar o que se convencionou chamar os paradoxos lógicos. As linguagens objetais constituem, portanto, linguagens artificiais, pois elas não existem e são formuladas a partir de regras estabelecidas na metalinguagem. Elas são formais, no sentido de que são 'cálculos não interpretados'" (OLIVEIRA, Manfredo Araújo de. Reviravolta linguístico-pragmática na filosofia contemporânea. São Paulo: Edições Loyola, 1996, p. 75). 


\section{A FILOSOFIA DA LINGUAGEM ORDINÁRIA E A (INESCAPÁVEL)}

INDETERMINAÇÃO DO DIREITO

havidas no círculo de Viena ${ }^{38}$ - berço do empirismo lógico ${ }^{39}$-, o resultado do interrogar filosófico diria respeito à linguagem, e não ao mundo, de modo que tais perguntas deveriam ser formuladas na metalinguagem ${ }^{40}$.

${ }^{38}$ Sobre a relação de Carnap com o círculo de Viena, Manuel Garrido, na introdução formulada a sua autobiografia, assevera: "cuando vio la luz el manifiesto 'Wissenschaftliche Weltauffassung. Der Wiener Kreis”, 1929 ('La concepción científica del mundo. El Círculo de Viena'), hacia ya tres anos que Carnap enseñaba en la Universidad vienesa y se había incorporado a aquel Círculo, iniciado por el físico y filosófo Moritz Schlick, en el que jugaron también un papel decisivo, juntamente con Carnap, el sociólogo Otto Neurath, el matemático y filósofo Friedrich Waismann y el físico Philipp Frank; al que se asoció el Círculo de Berlín de Hans Reichenbach; y por el que desfilaron personajes de la talla de Kurt Gödel, Bertrand Russel, Ludwig Wittgenstein y Karl Popper. Las tres coordenadas principales del Círculo: (1) el empirismo, que niega el conocimiento a priori del mundo, y con él la sínteses kantiana; (2) el positivismo, que otorga prioridade absoluta al conocimiento científico; y (3) la revolución lógica de Frege y Russel se resumían bastante bien, al menos a prima vista, en la etiqueta de 'empirismo lógico' o 'positivismo lógico', que en la medida de lo possibile procuraba hacer honor a los tres ingredientes" (GARRIDO, Manuel. Introducción: dos maneras de hacer filosofia. CARNAP, Rudolf. Autobiografía intelectual. Traducción de Carmen Castells. Barcelona: Editorial Paidós Ibérica, Universidad Autónoma de Barcelona, 1992, p. 11-12.

${ }^{39}$ É importante destacar que o empirismo lógico, também muitas vezes referido como neopositivismo lógico, sofre maiores influências do empirismo cético de David Hume do que do positivismo de Augusto Comte. A nomenclatura "neopositivismo lógico" pode levar a crer que toda essa filosofia estaria vinculada apenas com o positivismo de Comte, razão pela qual se faz essa ressalva. Nesse sentido, afirma Rosenberg: Among all the philosophers who wrote before the twentieth century none is more important for the philosophy of science than David Hume. This is because Hume is widely recognized to have been the chief philosophical inspiration of the most important twentieth century school in the philosophy of science - the so-called logical positivists. These philosophers began to work in Vienna in the late twenties, but by the end of the Second World War most of them had come to the United States. Many of them preferred the name logical empiricists, in part to emphasize their greater debt to Hume than to Comte". ROSENBERG, Alexander. Hume and the philosophy of science. In: The Cambridge Companion to Hume. Cambridge: Cambridge University Press, 2006, p. 64.

${ }^{40}$ OLIVEIRA, Manfredo Araújo de. Reviravolta linguístico-pragmática na filosofia contemporânea. São Paulo: Edições Loyola, 1996, p. 80. Nesse sentido, "sua convicção era de que a maioria dos problemas filosóficos autênticos era controvérsia a respeito do quadro linguístico adequado a uma pesquisa científica ou descritiva sobre os fatos 
A questão principal residia nas frases pseudo-objetais, ou seja, frases cuja construção gramatical, apesar de idêntica a das frases objetais, não fala de objetos do meio ambiente, mas de construções linguísticas. Distingui-las e tratá-las como frases sintáticas permitiria resolver os problemas filosóficos de modo correto e seguro. Consequentemente, esses problemas seriam, na verdade, problemas de sintaxe lógica ${ }^{41}$.

No entanto, posteriormente, o próprio Carnap reconheceu a impossibilidade de considerações puramente sintáticas da linguagem para a reflexão filosófica sobre a linguagem humana. Sob a influência de Tarski ${ }^{42}$, deu um passo adiante na sua teoria a partir da integração da sintaxe com a semântica ${ }^{43}$.

Assim, em toda aplicação da linguagem deveriam ser levados em conta três fatores principais: o falante, a expressão pronunciada e o designado pela expressão, isto é, aquilo que o falante pretende referir na expressão. Consequentemente, na semiótica - a teoria geral dos signos e da linguagem - três campos devem ser distinguidos: se a investigação faz referência explícita ao falante, ou, em termos mais gerais, àquele que faz uso da linguagem, ela está no campo da pragmática; se é abstraído quem utiliza a linguagem e é analisada apenas as expressões e sua designação,

dos quais tais pesquisas tratam". Assim, "as confusões existentes na filosofia provêm do fato de que os filósofos não terem clareza a respeito dessa realidade, isto é que as perguntas filosóficas são, nesse sentido, perguntas puramente linguísticas" (OLIVEIRA, Manfredo Araújo de. Reviravolta linguístico-pragmática na filosofia contemporânea. São Paulo: Edições Loyola, 1996, p. 81).

${ }^{41}$ OLIVEIRA, Manfredo Araújo de. Reviravolta linguístico-pragmática na filosofia contemporânea. São Paulo: Edições Loyola, 1996, p. 82.

42 Essa influência da Tarski na semântica de Carnap pode ser visualizada tanto na sua autobiografia, quanto na sua introdução à semântica, na qual, ainda no seu prefácio, Carnap menciona que Tarski, mediante o seu livro, bem como em conversas, teria sido o primeiro a chamar a sua atenção para o fato de que o método formal da sintaxe deveria ser suplementado por conceitos semânticos e que tais conceitos poderiam ser definidos de maneiras não menos exatas que aqueles da sintaxe (CARNAP, Rudolf. Introduction to semantics. Third printing. Cambridge - Massachusetts: Harvard University Press, 1948, p. vi).

43 CARNAP, Rudolf. Autobiografía intelectual. Traducción de Carmen Castells. Barcelona: Editorial Paidós Ibérica, Universidad Autónoma de Barcelona, 1992, p. 110. Nesse sentido, Carnap vai dizer que “o campo teórico da filosofia não é restrito à sintaxe, mas compreende toda a análise da linguagem, incluindo sintaxe e semântica e talvez também a pragmática" (CARNAP, Rudolf. Introduction to semantics. Third printing. Cambridge - Massachusetts: Harvard University Press, 1948, p. 246). 
ela está no campo da semântica; se é abstraída também a designação, e analisada apenas as relações entre as expressões, ela está no campo da (lógica) sintáxica ${ }^{44}$.

Nessa linha, a semântica contém a teoria daquilo que é usualmente chamado de significado das expressões (meaning of expressions) ${ }^{45}$. Porém, a investigação semântica pode se dar em dois diferentes tipos. Ela pode ser uma semântica descritiva, que cuida da descrição e análise das características semânticas ou particularidades históricas de uma determinada língua ou toda a história das línguas em geral, ou uma semântica pura, que cuida da análise dos sistemas semânticos, isto é, das regras de um sistema semântico ${ }^{46}$. Para Carnap e para o positivismo lógico interessa essa última concepção. Inclusive, essa divisão marca a separação entre o positivismo lógico e a filosofia da linguagem ordinária ${ }^{47}$.

Com efeito, a semântica se apresenta quando as regras sintáticas são completadas por regras de designação, que especificam as coisas às quais as expressões linguísticas e as regras de verdade fazem referência. Nesse contexto, ele desenvolve a distinção entre extensão e intensão $0^{48}$, para lidar com as relações que concernem à linguagem e aquilo a que ela se refere. A teoria da extensão lida com conceitos tais como denotar, nomear, extensão, verdade e outros vinculados a estes; a teoria da intensão, por sua vez, trabalha com conceitos tais como intensão, sinonímia, analiticidade e outros vinculados a estes. O termo intensão é utilizado

44 CARNAP, Rudolf. Introduction to semantics. Third printing. Cambridge Massachusetts: Harvard University Press, 1948, p. 09.

45 CARNAP, Rudolf. Introduction to semantics. Third printing. Cambridge Massachusetts: Harvard University Press, 1948, p. 10.

46 CARNAP, Rudolf. Introduction to semantics. Third printing. Cambridge Massachusetts: Harvard University Press, 1948, p. 11-12.

${ }^{47}$ Conforme Warat, o positivismo lógico, "centrado na semiótica pura, procura abordar a constituição de linguagens ideais que servem de modelos na obtenção de discursos mais rigorosos para a ciência", enquanto que a filosofia da linguagem ordinária "baseando-se na semiótica descritiva, centra-se na compreensão das impressões e possíveis distorções que surgem da falta de entendimento do funcionamento da língua natural" (WARAT, Luis Alberto. O direito e sua linguagem. Com a colaboração de Leonel Severo Rocha. 2a versão. Porto Alegre: Sérgio Fabris, 1984, p. 39).

48 OLIVEIRA, Manfredo Araújo de. Reviravolta linguístico-pragmática na filosofia contemporânea. São Paulo: Edições Loyola, 1996, p. 84. 
como termo técnico que designa o significado de uma expressão ou, mais especificamente, seu componente de significado designativo ${ }^{49}$.

Conforme Manfredo de Oliveira, essa distinção é vista, em primeiro lugar, a partir dos predicados, de modo que "a intensão de um predicado é sua significação, isto é, um conceito, enquanto a extensão é a classe dos objetos subsumíveis sob esse conceito" ${ }^{\prime 50}$. A designação de uma intensão (significado) é uma hipótese empírica que, como qualquer outra hipótese linguística, pode ser testada por observações do comportamento linguístico; a tese extensionalista, por seu turno, afirma que a designação de uma intensão, com base na extensão previamente determinada, não é uma questão de fato, mas, sim, de escolha. O linguista tem, portanto, a liberdade de escolher qualquer uma das propriedades que se ajustam à extensão dada ${ }^{51}$.

É importante registrar que a concepção filosófica de Carnap "gestouse no contexto da discussão do positivismo lógico, sobretudo no seio da teoria das sentenças da linguagem humana" ${ }^{22}$. Isso significa que somente podem ser submetidas a critérios científicos as sentenças que exprimem fatos ou conteúdo de pensamento redutíveis ao que é percebido pela sensibilidade e as sentenças que exprimem as regras do pensamento exato, como as regras da lógica formal e da matemática ${ }^{53}$. Ele insere-se naquilo que se chama filosofia da redução, como bem destaca Manuel Garrido na introdução da autobiografia de Carnap ${ }^{54}$. Desse modo, todas

${ }^{49}$ CARNAP, Rudolf. Significado e sinonímia nas linguagens naturais. In: SCHLICK, Moritz; CARNAP, Rudolf. Coletânea de textos. 3. ed. São Paulo, SP: Nova Cultural, 1988, p. 129.

50 OLIVEIRA, Manfredo Araújo de. Reviravolta linguístico-pragmática na filosofia contemporânea. São Paulo: Edições Loyola, 1996, p. 84.

51 CARNAP, Rudolf. Significado e sinonímia nas linguagens naturais. In: SCHLICK, Moritz; CARNAP, Rudolf. Coletânea de textos. 3. ed. São Paulo, SP: Nova Cultural, 1988, p. 131.

52 OLIVEIRA, Manfredo Araújo de. Reviravolta linguístico-pragmática na filosofia contemporânea. São Paulo: Edições Loyola, 1996, p. 85.

53 OLIVEIRA, Manfredo Araújo de. Reviravolta linguístico-pragmática na filosofia contemporânea. São Paulo: Edições Loyola, 1996, pp. 85-86.

${ }^{54}$ Nesse sentido, "fue Feigl, hasta hace poco tempo uno de los escasos supervenientes del Círculo de Viena, quien caracterizó a esos dos modos de pensamiento, como filosofía de la 'sedución' y filosofía de la 'reducinón'. El filosofo de la seducción quisera siempre encontrar 'algo más' en la realidade: que no haya sólo cosas, sino además personas, que no haya sólo materia, sino además libertad, que no haya sólo física, sino además metafísica, o por lo menos ética. El filósofo de la reducción pretende a toda 
as demais sentenças da linguagem humana se reportariam ao campo do empiricamente incontrolável, à metafísica ${ }^{55}$.

Por isso que, em Carnap, não compete à filosofia o conhecimento do mundo, mas somente a instância na qual são expressos os fatos do mundo, no caso, a linguagem. $\mathrm{O}$ conhecimento da realidade, portanto, ocorre nas ciências empíricas, as quais exprimem seus conhecimentos em sentenças. Desse modo, a filosofia resume-se a análise lógica da linguagem científica. Seu mister é "considerar a linguagem científica em reação a sua consistência lógica e ao sentido de suas sentenças" ${ }^{\prime \prime 6}$. A filosofia é, portanto, estrutural. Ela estuda a estrutura que torna possível o conhecimento dos fatos do mundo, a estrutura na qual o mundo se diz: a linguagem ${ }^{57}$.

A questão da verdade - elemento central da semântica - depende da formulação sintática da expressão linguística e também do elemento

limitar la realidade a 'nada más' que uno o algunos de sus aspectos elementos, como hace, por ejemplo, la ciencia física com los objetos que investiga" (GARRIDO, Manuel. Introducción: dos maneras de hacer filosofia. CARNAP, Rudolf. Autobiografía intelectual. Traducción de Carmen Castells. Barcelona: Editorial Paidós Ibérica, Universidad Autónoma de Barcelona, 1992, p. 09).

${ }^{55}$ Nesse sentido, a tradição do pensamento ocidental estaria marcada por um grande mal-entendido, pois a expressão adequada para o campo do empiricamente incontrolável não seria a filosofia, mas a arte: “a filosofia não passa de uma arte mal compreendida, pois pretende um conhecido válido sobre o real, isto é, conhecimento científico, mas este se reduz, por um lado, às ciências exatas da natureza e, por outro, à lógica e à matemática. A lógica e a matemática são um conhecimento puramente formal: nada dizem sobre a realidade, são saberes sem conteúdo, puras tautologias, enquanto o saber de conteúdo só nos pode ser dado pela percepção sensível e não por meio da reflexão pura, sem qualquer controle empírico como pretende a filosofia tradicional, a metafísica. Daí o famoso 'critério de verdade' do neopositivismo, o princípio empírico de verificação: somente sentenças de conteúdo podem ser verdadeiras ou falsas; portanto, só têm sentido as proposições que podem ser univocamente reduzidas a fatos de percepção. Todo conhecimento fundado radica nos fatos fornecidos por nossos sentidos. Não há, portanto, ciência não empírica do real" (OLIVEIRA, Manfredo Araújo de. Reviravolta linguístico-pragmática na filosofia contemporânea. São Paulo: Edições Loyola, 1996, p. 86).

${ }^{56}$ OLIVEIRA, Manfredo Araújo de. Reviravolta linguístico-pragmática na filosofia contemporânea. São Paulo: Edições Loyola, 1996, p. 87.

57 OLIVEIRA, Manfredo Araújo de. Reviravolta linguístico-pragmática na filosofia contemporânea. São Paulo: Edições Loyola, 1996, p. 89. 
semântico, o qual se caracteriza quando a expressão pode ser empregada para subministrar uma informação verificável sobre o mundo, vale dizer, se tem correspondência com os fatos. Assim, "um enunciado não será semanticamente significativo se não for empiricamente verificável" 58 .

Tudo isso deixa evidenciado o papel desempenhado por Carnap no âmbito da filosofia analítica e do positivismo lógico. A linguagem, embora aqui seja considerada o elemento central da filosofia, é depurada a partir de uma análise lógica, que reduz o âmbito de abrangência da filosofia, que deve se realizar pela análise da linguagem ${ }^{59}$.

Estabelecidas essas premissas torna-se possível elevar a ponte que vai da filosofia analítica à filosofia da linguagem ordinária. Entre essas duas correntes do pensamento filosófico, ou melhor, nas duas correntes, está Ludwig Wittgenstein ${ }^{60}$. Este filósofo, nas duas fases do seu pensamento,

58 WARAT, Luis Alberto. O direito e sua linguagem. Com a colaboração de Leonel Severo Rocha. 2a versão. Porto Alegre: Sérgio Fabris, 1984, p. 41. Sobre isso, bastante esclarecedora a lição de Luis Alberto Warat: “assim, por exemplo, a sequência de signos 'a cadeira é branca' é um enunciado ao qual se pode aplicar o predicado verdadeiro, já que expressa um fato que efetivamente pode ocorrer. Ao contrário, a série 'os duendes se apaixonam em maio' é um enunciado semanticamente sem sentido, porque não se refere a nenhum fato ou situação que efetivamente possa ocorrer ou sua existência seja admissível. Desta forma, verifica-se que para o positivismo lógico, a nível semântico, a verdade opera como um critério ou condição de sentido" (WARAT, Luis Alberto. O direito e sua linguagem. Com a colaboração de Leonel Severo Rocha. 2a versão. Porto Alegre: Sérgio Fabris, 1984, pp. 40-41).

${ }^{59}$ Pode-se dizer que "o positivismo lógico caracteriza-se pela preocupação com a fundamentação da ciência em uma linguagem lógica e em bases empíricas, eliminando os elementos metafísicos (como essências e formas) e psicológicos (como ideias e representações mentais), considerados inverificáveis, ou seja, fora do alcance do teste empírico, adotado como critério de validade das teorias científicas. Em termos gerais, a filosofia analítica pode ser caracterizada por ter como ideia básica a concepção de que a filosofia deve realizar-se pela análise da linguagem. Sua questão central seria então, pelo menos em primeiro momento, 'Como uma proposição tem significado?'. É nesse sentido que, nessa concepção de filosofia, o problema da linguagem ocupa um lugar central" (MARCONDES, Danilo. Filosofia analítica. Rio de Janeiro: Jorge Zahar, 2004, p. 12).

${ }^{60}$ Como bem destaca Manfredo de Oliveira ao tratar da obra de Wittgenstein, "duas correntes de pensamento se acham, de modo especial, ligadas a ele: o empirismo lógico ou neopositivismo do Círculo de Viena, que se liga à primeira filosofia de Wittgenstein, ou seja, à do Tractatus, e a filosofia da linguagem ordinária ao Wittgenstein da segunda fase - a das Investigações Filosóficas" (OLIVEIRA, Manfredo 
dedica-se à questão fundamental envolvendo a linguagem e o pensamento ${ }^{61}$, razão pela qual será objeto de análise aprofundada no tópico seguinte.

\section{WITTGENSTEIN E A FILOSOFIA DA LINGUAGEM ORDINÁRIA}

$\mathrm{Na}$ primeira fase do seu pensamento, Wittgenstein desenvolve sua teoria da figuração do mundo. Mundo, para ele, é a totalidade dos fatos, não das coisas ${ }^{62}$. O pensamento é a figuração lógica dos fatos, enquanto que a totalidade dos pensamentos verdadeiros é a figuração do mundo ${ }^{63}$. A correspondência entre pensamento e mundo só é possível quando ambos têm algo em comum. É o que ele chama de forma da afiguração, que é a "forma lógica" 64 . Essa identidade entre pensamento e realidade pode ser considerada como uma espécie de "isomorfia"65. Ela se dá, no

Araújo de. Reviravolta linguístico-pragmática na filosofia contemporânea. São Paulo: Edições Loyola, 1996, p. 94).

${ }^{61}$ OLIVEIRA, Manfredo Araújo de. Reviravolta linguístico-pragmática na filosofia contemporânea. São Paulo: Edições Loyola, 1996, p. 95.

${ }^{62}$ WITTGENSTEIN, Ludwig. Tractatus logico-philosophicus. Tradução e apresentação de José Arthur Giannotti. São Paulo: Companhia editora nacional - Editora da universidade de São Paulo, 1968, p. 55.

${ }^{63}$ WITTGENSTEIN, Ludwig. Tractatus logico-philosophicus. Tradução e apresentação de José Arthur Giannotti. São Paulo: Companhia editora nacional - Editora da universidade de São Paulo, 1968, p. 61.

${ }^{64}$ OLIVEIRA, Manfredo Araújo de. Reviravolta linguístico-pragmática na filosofia contemporânea. São Paulo: Edições Loyola, 1996, p. 102. Nesse sentido: “2.6 Os fatos, para serem figuração, devem ter algo em comum com o que é afigurado. 2.161 Deve haver algo idêntico na figuração e no afigurado a fim de que um possa ser a figuração do outro. $2.17 \mathrm{O}$ que a figuração deve ter em comum com a realidade para poder afigurar à sua maneira - correta ou falsamente - é sua forma de afiguração. (...) 2.18 O que cada figuração, de forma qualquer, deve sempre ter em comum com a realidade para poder afigurá-la em geral - correta ou falsamente - é a forma lógica, isto é, a forma da realidade. 2.181 Se $a$ forma da afiguração é a forma lógica, a figuração chamase lógica" (WITTGENSTEIN, Ludwig. Tractatus logico-philosophicus. Tradução e apresentação de José Arthur Giannotti. São Paulo: Companhia editora nacional Editora da universidade de São Paulo, 1968, p. 60).

${ }^{65}$ Conforme Manfredo de Oliveira, essa relação de correspondência entre os dois polos (mundo e pensamento) na obra de Wittgenstein, "foi muitas vezes compreendida e interpretada como uma relação isomórfica (Stenius, Stegmüller, Kutschera). Tai 
Tractatus, a partir de uma identidade estrutural. Portanto, uma figuração somente será perfeita quando houver uma identidade de estrutura interna e externa, de modo que a identidade da estrutura externa pressupõe a identidade da estrutura interna, tratando-se, pois, de uma identidade estrutural ${ }^{66}$.

O pensamento é, no Tractatus, uma proposição significativa. É que a proposição, nesse sentido, é uma figuração da realidade, é o modelo da realidade tal como é pensada ${ }^{67}$. Assim, a totalidade das proposições é a linguagem. Por isso, nele Wittgenstein vai dizer que a linguagem veda o pensamento ${ }^{68}$ e que "os limites de minha linguagem denotam os limites do meu mundo"69. É nesse sentido que "na proposição o nome substitui o objeto" e que os signos substituem os objetos, não sendo possível enunciá-los, mas somente falar sobre eles. Dito de outro modo, "uma proposição pode apenas dizer como uma coisa é, mas não o que é" 70 .

Nesse contexto, Wittgenstein vai cobrar um rigor linguístico pois é devido à possibilidade de uma mesma palavra designar de modos diferentes ou, ainda, de duas palavras serem empregadas na proposição superficialmente da mesma maneira, que nasceriam as confusões mais fundamentais, de que toda a filosofia estaria plena ${ }^{71}$. Para evitar esses

interpretação parece-me capaz de exprimir a intenção fundamental de Wittgenstein" (OLIVEIRA, Manfredo Araújo de. Reviravolta linguístico-pragmática na filosofia contemporânea. São Paulo: Edições Loyola, 1996, p. 102).

66 OLIVEIRA, Manfredo Araújo de. Reviravolta linguístico-pragmática na filosofia contemporânea. São Paulo: Edições Loyola, 1996, p. 103.

${ }^{67}$ WITTGENSTEIN, Ludwig. Tractatus logico-philosophicus. Tradução e apresentação de José Arthur Giannotti. São Paulo: Companhia editora nacional - Editora da universidade de São Paulo, 1968, p. 71.

68 WITTGENSTEIN, Ludwig. Tractatus logico-philosophicus. Tradução e apresentação de José Arthur Giannotti. São Paulo: Companhia editora nacional - Editora da universidade de São Paulo, 1968, p. 70.

${ }^{69}$ WITTGENSTEIN, Ludwig. Tractatus logico-philosophicus. Tradução e apresentação de José Arthur Giannotti. São Paulo: Companhia editora nacional - Editora da universidade de São Paulo, 1968, p. 111.

70 WITTGENSTEIN, Ludwig. Tractatus logico-philosophicus. Tradução e apresentação de José Arthur Giannotti. São Paulo: Companhia editora nacional - Editora da universidade de São Paulo, 1968, p. 111.

71 Assim: "na linguagem corrente amiúde acontece que a mesma palavra designa de modos diferentes - pertencente, pois, a símbolos diferentes - ou ainda duas palavras, que designam de modos diferentes, são empregadas na proposição superficialmente da mesma maneira. Assim a palavra 'é' aparece como cópula; como sinal de igualdade 
erros, Wittgenstein defende o uso de uma linguagem simbólica que seja capaz de excluí-los, de modo que não seja empregado superficialmente o mesmo signo para símbolos diferentes, nem sejam empregados signos que de designam, de maneira diversa, do mesmo modo. Vale dizer, uma linguagem que obedeça à gramática lógica (à sintaxe lógica) ${ }^{72}$. É assim que a construção do mundo pela proposição se dá com “a ajuda de andaimes lógicos"73-74.

É certo que Wittgenstein se distancia, em alguns pontos, da semântica tradicional, notadamente por conceber a função da linguagem não somente como designação e expressão, mas, também, como correspondência da estrutura categorial das expressões à estrutura categorial da realidade. No entanto, não se pode obscurecer o fato de sua semântica desenvolver de modo muito preciso os pressupostos ontológicos da semântica tradicional ${ }^{75}$.

e expressão da existência; 'existir', enquanto verbo intransitivo do mesmo modo que 'ir'; 'idêntico', enquanto adjetivo: falamos respeito de algo, mas também de que algo acontece. (Na proposição 'Rosa é rosa' ('Grün ist grün') - onde a primeira palavra é nome de pessoa e a última é adjetivo - ambas as palavras não têm apenas denotações diferentes, mas constituem símbolos diferentes). Nascem assim as confusões mais fundamentais (de que toda a filosofia está plena)" (WITTGENSTEIN, Ludwig. Tractatus logico-philosophicus. Tradução e apresentação de José Arthur Giannotti. São Paulo: Companhia editora nacional - Editora da universidade de São Paulo, 1968, p. 66).

72 WITTGENSTEIN, Ludwig. Tractatus logico-philosophicus. Tradução e apresentação de José Arthur Giannotti. São Paulo: Companhia editora nacional - Editora da universidade de São Paulo, 1968, p. 67.

73 WITTGENSTEIN, Ludwig. Tractatus logico-philosophicus. Tradução e apresentação de José Arthur Giannotti. São Paulo: Companhia editora nacional - Editora da universidade de São Paulo, 1968, p. 72.

${ }^{74}$ Conforme leciona Paulo Roberto Margutti Pinto, a lógica na filosofia tractatiana atua em dois níveis, a saber: "no nível dos fatos atômicos, a forma lógica é a condição de possibilidade de a proposição retratar isomorficamente o fato". Já o segundo nível, "das combinações lógicas das proposições elementares entre si e dos fatos atômicos entre si, a lógica é condição de possibilidade da constituição das proposições complexas e dos fatos complexos". In: MARGUTTI PINTO, Paulo Roberto. O Tractatus de Wittgenstein como obra de iniciação. Filosofia Unisinos. vol. 5. n. 8. São Leopoldo: Editora Unisinos, 2004, p. 91.

75 OLIVEIRA, Manfredo Araújo de. Reviravolta linguístico-pragmática na filosofia contemporânea. São Paulo: Edições Loyola, 1996, p. 61. 
O que está em jogo aqui, a partir da abordagem obra de Wittgenstein é verificar a guinada no seu pensamento com a sua obra Investigações Filosóficas, que marca a segunda fase do seu pensamento, na qual ele desenvolve "uma crítica radical à tradição filosófica ocidental da linguagem, cuja expressão última havia sido precisamente o Tractatus" ${ }^{\prime \prime}$. Agora, então, Wittgenstein vai se colocar contra a tradição do pensamento ocidental fundada na ideia de uma isomorfia entre realidade e linguagem, vale dizer, a ideia de que a palavra serve para designar diferentes objetos que possuem uma determinada essência - aquilo que é comum a várias coisas individuais, o conceito $^{77}$. O Tractatus era justamente a última forma dessa teoria, que servia de alicerce à teoria da figuração.

Para Wittgenstein, não se deve buscar a essência da linguagem, mas, sim, indagar como ela funciona. A atitude metafísica, portanto, deve ser substituída pela atitude prática ${ }^{78}$. Deve-se, pois, reconduzir as palavras

75 OLIVEIRA, Manfredo Araújo de. Reviravolta linguístico-pragmática na filosofia contemporânea. São Paulo: Edições Loyola, 1996, p. 113-114.

${ }^{76}$ OLIVEIRA, Manfredo Araújo de. Reviravolta linguístico-pragmática na filosofia contemporânea. São Paulo: Edições Loyola, 1996, p. 117.

77 OLIVEIRA, Manfredo Araújo de. Reviravolta linguístico-pragmática na filosofia contemporânea. São Paulo: Edições Loyola, 1996, p. 117. Como bem destaca Coreth, desde o Crátilo de Platão e sobretudo nos escritos lógicos de Aristóteles, "tornou-se predominante a concepção da linguagem como simples sistema convencional de sinais para designar conteúdos já pensados, visando a compreensão na sociedade. A palavra refere-se ao conceito, e a linguagem à essência das coisas. Quanto mais se procura atingir pelo pensamento a essência eterna e imutável, mas se deve entender e apreciar a linguagem como pertencente a este mundo passageiro e transitório(...). Essa concepção da linguagem, na qual aparece em primeiro plano a função designadora dos objetos, mas não se divisa mais a totalidade viva do acontecimento linguístico em sua primitiva função criadora e reveladora do sentido, penetra na tradição de quase toda filosofia ocidental. Ela fica valendo para a filosofia estóica da linguagem, do mesmo modo que para a escolástica medieval, tanto para o realismo como para o nominalismo na disputa dos universais, ou até para Guilherme de Ockham, embora este critique a partir do uso concreto da linguagem, a concepção realista de Platão" (CORETH, Emerich. Questões fundamentais de hermenêutica. Tradução de Carlos Lopes de Matos. São Paulo: EPU, Ed. da Universidade de São Paulo, 1973, p. 27).

${ }^{78}$ D'OLIVEIRA, Armando. Wittgenstein - Vida e Obra. In: WITTGENSTEIN, Ludwig. Investigações filosóficas. Tradução: José Carlos Bruni. São Paulo: Nova Cultural, 1999, p. 14. 
do seu emprego metafísico para o seu emprego cotidiano ${ }^{79}$. É desse modo que ele vai acusar de insuficiente função designativa das palavras, uma vez que elas não designam algo teórico e de maneira unívoca para, depois, serem usadas nessa ou naquela acepção. Ao contrário, elas primeiro são empregadas na vida cotidiana, constituindo esse emprego cotidiano a sua significação ${ }^{80}$.

Com efeito, denominar algo consiste em colocar uma etiqueta numa coisa $^{81}$, sem que isso importe na possibilidade de se alcançar uma espécie de exatidão da linguagem ${ }^{82}$, como se almejava no Tractatus. Wittgenstein utiliza o termo jogos de linguagem ${ }^{83}$, para salientar que "o falar da linguagem é uma parte de uma atividade ou de uma forma de vida" 84 . Com isso, a significação das palavras não pode ser estabelecida de modo definitivo, mas, sim, que seu significado depende de uma consideração do contexto socioprático em que é utilizada ${ }^{85}$.

${ }^{79}$ WITTGENSTEIN, Ludwig. Investigações filosóficas. Tradução: José Carlos Bruni. São Paulo: Nova Cultural, 1999, p. 66.

${ }^{80}$ CORETH, Emerich. Questões fundamentais de hermenêutica. Tradução de Carlos Lopes de Matos. São Paulo: EPU, Ed. da Universidade de São Paulo, 1973, p. 33.

${ }^{81}$ WITTGENSTEIN, Ludwig. Investigações filosóficas. Tradução: José Carlos Bruni. São Paulo: Nova Cultural, 1999, p. 32.

82 WITTGENSTEIN, Ludwig. Investigações filosóficas. Tradução: José Carlos Bruni. São Paulo: Nova Cultural, 1999, p. 61.

${ }^{83}$ Conforme Stegmüller, "a expressão 'jogo de linguagem' não surge por acaso. O aspecto sob o qual Wittgenstein contempla a linguagem leva, quase que necessariamente, à comparação da linguagem como um jogo complicado como, por exemplo, o xadrez. Sob múltiplos aspectos, a analogia evidencia-se frutífera. Antes de tudo, é o ponto de vista operativo que aparece em primeiro plano, para Wittgenstein. A realização de um jogo consiste em determinado operar com figuras de jogo: a concretização da linguagem na condição de um jogo de linguagem consiste em um operar com palavras e frases. No primeiro caso, o operar com figuras de jogo é governado por certas regras; analogamente, no segundo caso, o operar com expressão linguística também se processa em consonância com algumas regras" (STEGMÜLLER, Wolfgang. A Filosofia Contemporânea: Introdução Crítica. 2․․ Rio de Janeiro Forense 2012, p. 418).

${ }^{84}$ WITTGENSTEIN, Ludwig. Investigações filosóficas. Tradução: José Carlos Bruni. São Paulo: Nova Cultural, 1999, p. 35.

${ }^{85}$ WITTGENSTEIN, Ludwig. Investigações filosóficas. Tradução: José Carlos Bruni. São Paulo: Nova Cultural, 1999, p. 61. 
Nisso, fica caracterizada uma diferença essencial do projeto filosófico de Wittgenstein - filosofia da linguagem ordinária - em relação ao positivismo lógico. É que a filosofia da linguagem ordinária trabalha, segundo Warat, em um nível de análise privilegiado, que é o nível da pragmática, enquanto o positivismo lógico contenta-se com uma análise sintática e semântica da linguagem ${ }^{86}$.

Ao invés de compreender e formular regras de uma "gramática profunda", caberia muito mais à filosofia, segundo Wittgenstein, fazer uma análise das situações pragmáticas presentes nos diversos jogos de linguagem ${ }^{87}$. A filosofia, com efeito, não deveria tocar no uso efetivo da linguagem, mas apenas descrevê-lo ${ }^{88}$. Essa descrição, no entanto, opera já no plano do uso da linguagem, no campo da pragmática, o que representa um sensível avanço em relação à tradição semântica que precedeu as investigações filosóficas de Wittgenstein.

Pode-se ver que a linguagem ocupa, no segundo Wittgenstein, um novo papel, diverso, portanto, daquele que ocupava na filosofia linguística semântica que vinha de Frege até Carnap e os demais seguidores do círculo de Viena. Desse modo, a linguagem passa a ser condição de possibilidade do próprio conhecimento, deixando de ser um mero instrumento à disposição do homem: "não existe um mundo em si independente da linguagem, que deveria ser copiado por ela", como queria Wittgenstein no Tractatus. Assim, conforme precisa leitura que Manfredo de Oliveira faz da sua obra, "isso significa, de fato, apesar de não ser expresso em Wittgenstein com toda clareza em virtude do próprio caráter assistemático de sua obra, a descoberta da transcendentalidade da linguagem humana, de seu caráter transcendental" 89 .

Nesse sentido, o pensamento de Wittgenstein aproxima-se, de certo modo, ao pensamento de Humboldt, na medida em que a linguagem não

85 OLIVEIRA, Manfredo Araújo de. Reviravolta linguístico-pragmática na filosofia contemporânea. São Paulo: Edições Loyola, 1996, p. 131.

${ }^{86}$ WARAT, Luis Alberto. O direito e sua linguagem. Com a colaboração de Leonel Severo Rocha. $2^{\underline{a}}$ versão. Porto Alegre: Sérgio Fabris, 1984, p. 64.

${ }^{87}$ STEGMÜLLER, Wolfgang. A Filosofia Contemporânea: Introdução Crítica. $2^{a}$. Rio de Janeiro Forense 2012, p. 422.

${ }_{88}$ WITTGENSTEIN, Ludwig. Investigações filosóficas. Tradução: José Carlos Bruni. São Paulo: Nova Cultural, 1999, p. 67.

${ }^{89}$ WITTGENSTEIN, Ludwig. Investigações filosóficas. Tradução: José Carlos Bruni. São Paulo: Nova Cultural, 1999, p. 128.

${ }^{89}$ OLIVEIRA, Manfredo Araújo de. Reviravolta linguístico-pragmática na filosofia contemporânea. São Paulo: Edições Loyola, 1996, p. 131. 
é aqui somente objeto de análise numa perspectiva científica, como queria o neopositivismo lógico. Na realidade, como afiança Coreth, "aqui também se trata de compreender o fenômeno linguístico individual por sua função no todo da vida humana, como contexto de significação, no qual ela está e do qual é falada" ${ }^{\prime \prime 0}$. Ainda que o método analítico não tenha sido de todo abandono no segundo Wittgenstein, trata-se, melhor dizendo, de uma pragmática analítica, no seio da qual a linguagem ocupa um lugar cimeiro, importado à investigação filosófica o seu estudo fundado na descrição dos seus usos, e não mediante explicações ao modo da ciência ${ }^{91}$.

As investigações filosóficas de Wittgenstein vão impulsionar o desenvolvimento da filosofia da linguagem ordinária, em frentes distintas $^{92}$, cabendo aqui ressaltar como seus expoentes, notadamente na matriz da escola de Oxford, Austin e Searl ${ }^{93}$. Essas teorias vão se aproximar da matriz hermenêutica pelo menos na medida em que cuidam de explicitar o contexto intersubjetivo (pragmático) em que o

${ }_{90}$ CORETH, Emerich. Questões fundamentais de hermenêutica. Tradução de Carlos Lopes de Matos. São Paulo: EPU, Ed. da Universidade de São Paulo, 1973, p. 34.

91 ROJAS OSORIO, Carlos. Genealogía del giro linguístico. Medellín: Editorial Universidad de Antioquia, 2006, p. 188. Rojas chega a dizer que, "en Wittgenstein el giro hermenêutico y el giro linguístico coincidem, pues el lenguaje se da desde la forma de vida de cada pueblo" (ROJAS OSORIO, Carlos. Genealogía del giro linguístico. Medellín: Editorial Universidad de Antioquia, 2006, p. 87).

${ }_{92}$ Conforme Warat, "no interior da filosofia da Linguagem Ordinária, podem ser indicadas duas grandes correntes, ainda que nenhuma deles tenha chegado a constituir uma escola organizada. Tais correntes ocupam-se em analisar questões parciais, em examinar isoladamente os problemas das linguagens ordinárias, sem procurar sua organização sistemática. O primeiro grupo aglutinou-se ao redor das ideias de Wittgenstein, tendo Malcom e Waismann como suas figuras mais destacadas. O segundo grupo está vinculado ao que se denominou Escola de Oxford, cujos membros mais importantes são: Ryle, Austin, Strawson, Hart e Hare. O traço distintivo mais marcante entre tais correntes é o fato de que os filósofos de Oxford foram menos obcecados na tentativa de evitar discussões metodológicas gerais e na procura de resultados particulares. Austin chega a insinuar a possibilidade de uma ciência da linguística" (WARAT, Luis Alberto. O direito e sua linguagem. Com a colaboração de Leonel Severo Rocha. $2^{a}$ versão. Porto Alegre: Sérgio Fabris, 1984, p. 63).

${ }_{93}$ Vale lembrar ainda que Herbert Hart assume explicitamente a influência da filosofia de Austin em suas obras. Ver HART, Herbert L. A. Essays in jurisprudence and philosophy. Oxford: Clarendon Press, 1983. 
sentido é gerado ${ }^{94}$. A sua influência fez, ainda, com que hoje, mesmo no terreno da filosofia analítica, apenas parcialmente se mantenham as teses neopositivistas, deixando de conceber como válida somente a linguagem científica para se preocupar, igualmente, com o sentido dos enunciados em geral, cujo sentido e possibilidade somente ocorre no todo vivo e na multiplicidade da linguagem natura ${ }^{95}$. Disso decorre o fato de que, para uma teoria analítica do direito, atualmente, os problemas da teoria do direito vão se resumir a questões de definição linguística, de modo que o significado das expressões jurídicas passa a ser encontrado de acordo com o uso que delas é feito na linguagem corrente ${ }^{96}$.

\section{IV.O PROBLEMA DA INDETERMINAÇÃO DO DIREITO NA PERSPECTIVA DA FILOSOFIA DA LINGUAGEM ORDINÁRIA}

A filosofia da linguagem ordinária, na medida em que passa a levar em consideração os usos da linguagem, permite que se possa explorar o significado dos termos linguísticos em dois níveis básicos de significação, quais sejam, o significado de base e o significado contextual. Como muito bem elucida Warat, o significado de base "é aquele que reconhecemos no plano teórico quando abstraímos a significação contextual e

94 Nesse sentido, STRECK, Lenio Luiz. Hermenêutica jurídica e(m) crise: uma exploração hermenêutica da construção do direito. $10^{\mathrm{a}}$ edição revista, atualizada e ampliada. Porto Alegre: Livraria do Advogado, 2011, p. 221. Sobre o tema, com mais vagar, ver OLIVEIRA, Manfredo Araújo de. Reviravolta linguístico-pragmática na filosofia contemporânea. São Paulo: Edições Loyola, 1996, p. 149-200.

${ }^{95}$ CORETH, Emerich. Questões fundamentais de hermenêutica. Tradução de Carlos Lopes de Matos. São Paulo: EPU, Ed. da Universidade de São Paulo, 1973, p. 34.

${ }_{96}^{96}$ SAARBRÜCKEN, Mazurek. Teoria analítica do direito. In: HASSEMER, A. Kaufmann

(Org.). Introdução à filosofia do direito e à teoria do direito contemporâneas. Tradução: Marcos Keel, Manuel Seca de Oliveira. Lisboa: Fundação Calouste Gulbekian, 2002, p. 371. Conforme Saarbrücken, “A teoria analítica do direito, na tradição inglesa de Bentham (1748-1821), passando por J. Austin (1790-1859), até Kelsen (1881-1973) e H.L.A. Hart (nascimento em 1907) é uma orientação integrada na chamada teoria positivista do direito, cuja fundamentação se deve a Hobbes (15881678)" (SAARBRÜCKEN, Mazurek. Teoria analítica do direito. In: HASSEMER, A. Kaufmann (Org.). Introdução à filosofia do direito e à teoria do direito contemporâneas. Tradução: Marcos Keel, Manuel Seca de Oliveira. Lisboa: Fundação Calouste Gulbekian, 2002, p. 369). 
consideramos o sentido congelado, a partir dos elementos de significação unificados por seus vínculos denotativos". Já o significado contextual pode ser entendido como um "efeito de sentido derivado dos processos efetivos da comunicação social" 97 .

A partir daí o problema da indeterminação do direito pode ser visualizado em duas perspectivas. Por um lado, muitas palavras, quando analisadas somente no plano do significado de base podem apresentar algumas características de sua estrutura denotativa e designativa que por si só impossibilitam uma significação plena. Por outro lado, diante do contexto - do uso da linguagem - uma expressão que, em abstrato, não apresentava problemas linguísticos pode dar margem a incertezas. Warat dá um bom exemplo nesse sentido a partir da expressão "proibido usar tanga", a qual tem um significado de base padronizado que, facilmente, remete o intérprete a uma peça do vestuário. Porém, o sentido da mensagem poderá mudar, conforme figure em um cartaz na praia de Ipanema ou na porta de entrada de um campo de nudismo: "a situação, em ambos os casos, indicar-nos-á a adoção de diferentes comportamentos em relação à tanga. Numa das hipóteses, usar uma peça de banho maior; em outra, nada usar" 98 .

Não se trata, certamente, de um problema recente na doutrina jurídica. Alf Ross, ainda na década de 50 , já reconhecia que a referência semântica da palavra tem uma zona central sólida, em que sua aplicação é predominantemente certa, e um nebuloso círculo exterior de incerteza, no qual sua aplicação é menos usual e no qual se torna mais duvidoso saber se a palavra pode ser aplicada ou não ${ }^{99}$. Com efeito, os problemas semânticos da interpretação seriam aqueles referentes ao significado das palavras individuais ou das frases. O problema decorreria do fato de muitas palavras serem ambíguas e que todas seriam vagas ${ }^{100}$.

A linguagem jurídica, enquanto linguagem de uma comunicação prática, não suscita apenas nem fundamentalmente o objetivo semântico da significação abstrata (lógico-linguística isolada) dos seus termos e

97 WARAT, Luis Alberto. O direito e sua linguagem. Com a colaboração de Leonel Severo Rocha. 2ª versão. Porto Alegre: Sérgio Fabris, 1984, p. 65.

98 WARAT, Luis Alberto. O direito e sua linguagem. Com a colaboração de Leonel Severo Rocha. 2a versão. Porto Alegre: Sérgio Fabris, 1984, p. 67.

${ }^{99}$ ROSS, Alf. Direito e justiça. Tradução Edson Bini. Revisão técnica Alysson Leandro Mascaro. Bauru, SP: EDIPRO, 2000, p. 142.

100 ROSS, Alf. Direito e justiça. Tradução Edson Bini. Revisão técnica Alysson Leandro Mascaro. Bauru, SP: EDIPRO, 2000, p. 164. 
expressões, e ainda que com o complemento sintático de significação obtido no respectivo contexto discursivo; procura antes uma projeção performativa e comunicacional só possível pela inserção dos seus enunciados no contexto social (sócio-histórico-cultural) e mediante uma leitura deles em função prático-hermenêutica desse contexto ${ }^{101}$. Há, nesse sentido, uma contínua tensão significante, somente sendo possível obterse o sentido dos enunciados jurídicos superando a distância significativa entre a significação semântica das expressões e o sentido práticohermenêutico do enunciado ${ }^{102}$.

Postas as coisas desse modo, cabe mencionar que três são os problemas linguísticos que avultam o caráter indeterminado do direito: a porosidade, a vagueza e ambiguidade. Conforme Friedrich Waismann, "um termo é definido quando descreve exatamente o tipo de situação na qual é para ser utilizado". Como, de fato, nunca é possível eliminar a possibilidade de algum fato imprevisto emergente, também não é possível ter certeza de que se incluiu na definição tudo o que deve ser incluído, de modo que o processo de definição e refinamento é uma ideia que vai continuar sem nunca atingir um estado final. Desse modo, "cada definição se estende para um horizonte aberto"103. Com efeito, todo conceito empírico, independentemente do modo pelo qual é definido, sempre parte de uma demarcação definitória pensada para casos normais, não se contando com casos inesperados ${ }^{104}$.

É nesse sentido, justamente, que Hart afirma que os legisladores humanos não podem ter conhecimento de todas as possíveis combinações de circunstâncias que o futuro pode trazer. Tal incapacidade de antecipar acarreta consigo uma relativa indeterminação de finalidade. Assim, quando uma norma traz uma regra geral de conduta, como, por exemplo, a regra de que nenhum veículo pode ser levado a um parque, a linguagem usada neste contexto estabelece as condições necessárias que qualquer

101 CASTANHEIRA NEVES, António. O princípio da legalidade criminal. In: Digesta: escritos acerca do direito, do pensamento jurídico, da sua metodologia e outros. Volume 1‥ Coimbra: Coimbra editora, 1995, p. 377.

102 CASTANHEIRA NEVES, António. O princípio da legalidade criminal. In: Digesta: escritos acerca do direito, do pensamento jurídico, da sua metodologia e outros. Volume 1ํ. Coimbra: Coimbra editora, 1995, p. 377-378.

103 WAISMANN, Friedrich. Verifiability. Analysis and metaphysics. Proceedings of the Aristotelian Society, Supplementary Volume XIX. London: Harrison and sons Ltda., 1945, p. 125.

104 STEGMÜLLER, Wolfgang. A filosofia contemporânea: introdução crítica. 2ª . Rio de Janeiro: Forense, 2012, p. 438. 
coisa deve satisfazer para se achar dentro do seu âmbito de aplicação, podendo, certamente, apresentarem-se exemplos claros do que cai dentro do seu âmbito (casos paradigmáticos e claros como o automóvel, o autocarro, o motociclo). Nesse caso, resolve-se, desde o início, a questão de que a paz e a tranquilidade no parque deviam ser mantidas à custa, em qualquer caso, da exclusão destas coisas. No entanto, até que se tenha colocado a finalidade geral da paz no parque em confronto com aqueles casos que não eram encarados inicialmente ou não poderiam ser encarados (talvez um automóvel de brinquedo, movido eletricamente), a finalidade é, nessa direção, indeterminada ${ }^{105}$.

Ocorre que as porosidades (textura aberta) são indeterminações referenciais provocadas quer pela sempre possível alteração ou novidade problemáticas, quer pela temporal modificação das situações e dos contextos práticos. Ela é intrínseca à linguagem, pois não se pode saber $a$ priori e uma vez por todas que problemas, casos ou circunstâncias futuras se oferecerão no seu horizonte de possível referência, pelo que a sua significação não se pode ter também nunca por definitivamente determinada. Daí se dizer que a porosidade considera a indeterminação relativamente a fenômenos ainda não conhecidos, como que se traduzindo numa vaguidade potencial ${ }^{106}$.

Como leciona Frederick Schauer, a textura aberta é uma característica indelével da linguagem, uma consequência do confronto entre a linguagem fixa e uma mudança contínua em um mundo desconhecido ${ }^{107}$. Desse modo, qualquer tentativa de construir um esquema conceitual preciso de certeza absoluta, cairia por terra. Afinal, "claramente, o arquétipo da certeza absoluta seria uma casuística infinita: uma casuística isto é que preveja todos os casos. Isso é impossível em razão da extrema variedade dos casos e pela historicidade da experiência humana"108.

A concepção da linguagem no segundo Wittgenstein se relaciona diretamente com a noção já esboçada de textura aberta de Waismann,

${ }^{105}$ HART, H. L. A. O conceito de Direito. Tradução de Antônio de Oliveira Sette Câmara. 1 ed. São Paulo: WMF Martins Fontes, 2012, p. 164, 167.

106 CASTANHEIRA NEVES, António. Metodologia jurídica: problemas fundamentais.

Coimbra: Coimbra Editora, 1993, p. 112.

107 SCHAUER, Frederick. Playing by the rules: a philosopical examination of rule-based decision-making in law and in life. New York: Oxford Claredon press, 2002, pp. 35-36. 108 VALLAURI, Luigi Lombardi. Norme vaghe e teoria generale del diritto. Ars interpretandi. Annuario di ermeneutica giuridica. L'intenzione nell'interpretazione. Padova: CEDAM, 1998, p. 160. 
denominada abertura dos conceitos por Stegmüller. Para este autor é possível elucidar melhor a ideia de abertura de conceitos, reportando-se justamente à tese de Wittgenstein de que o significado (na maioria das vezes) é o uso correto e se considerarmos que os conceitos (na maioria das vezes) são significados de expressões. Assim, é possível fixar regras para o uso, em determinadas situações pragmáticas e, deste modo, afastar ambiguidades e diminuir o campo de vaguidade. Contudo, enfatiza o filósofo alemão, isso tem um limite: a abertura dos conceitos repousa no fato de ser impossível estabelecer regras para todas as espécies e situações concebíveis. Por isso, uma expressão de fato, e rigorosamente delimitada, sempre encerraria possibilidade de vagueza. Todo conceito empírico, independentemente do modo pelo qual é definido, sempre parte de uma demarcação definitória pensada para casos normais, não se contando com casos inesperados ${ }^{109}$.

No entanto, faz-se necessário advertir que o problema da abertura dos conceitos não constitui, para o próprio Waismann, necessariamente um problema de vagueza ${ }^{110}$. Pelo contrário, textura aberta é algo distinto da vagueza, pois esta diz respeito ao uso flutuante da palavra ${ }^{111}$. Ainda, mais adequado seria traduzir a expressão Porosität der Begriffe por porosidade dos termos, e não por textura aberta, que foi utilizada por Waismann por

109 STEGMÜLLER, Wolfgang. A filosofia contemporânea: introdução crítica. $2^{a}$. Rio de Janeiro: Forense 2012, p. 438.

${ }^{110}$ Não somente Stegmüller confunde a questão da textura aberta com a vagueza. No âmbito da teoria do direito e da interpretação também Guastini trata como fenômenos imbricados a vagueza e a textura aberta: La vaghezza (la open texture, la trama aperta) - a differenza dell'equivocità - è una proprietà oggettiva del lingauggio, e non solo del lingauggio giuridico: tutti $\mathrm{i}$ predicati in senso logico condividono (almeno potenzialmente) questa proprietà. La vaghezza non dipende dunque dalla tecniche interprrtative o dalla dogmática: essa non può esser soppressa (acnhe se può essere ridotta per mezzo di definizioni). La vaghezza delle espressioni usate nel lingauggio delle fonti - che non è risolta dalla interpretazione in astratto - fa' sì che 1 'interrpete, di fronte ad um caso "marginale" cioè ad um caso che cade ai margini dela "tratama" - nella "área di penombra", come si usa dire - possa decidere discrezionalmente se la fattispecie in exame debba o non debba essere inclusa nel campo di applicazione della norma in questione (GUASTINI, Riccardo. Interpretare e argomentare. Milano: Dott. A. Giuffrè Editore, 2011, p. 56).

111 WAISMANN, Friedrich. Verifiability. Analysis and metaphysics. Proceedings of the Aristotelian Society, Supplementary Volume XIX. London: Harrison and sons Ltda., 1945, p. 123. 
sugestão do professor Kneale em razão da falta de um termo em inglês coincidente com o alemão ${ }^{112}$.

Daí a importância da distinção entre os dois níveis básicos de significação referidos, propostos por Warat, quais sejam, o significado de base e o significado contextual. Por sinal, a existência de um significado contextual deixa nítida, pois, a existência de "uma ilusão de univocidade fornecida pela inalterabilidade da instância sintática dos textos legais"113, na medida em que não há como fugir da problemática decorrente do uso flutuante das palavras. Por outro lado, deve-se ter presente que é justamente no significado de base que estão inseridos os problemas da vagueza e da ambiguidade dos termos gerais ${ }^{114}$. É acertado dizer, portanto, que os significados da linguagem natural apresentam uma significação incompleta se analisados exclusivamente ao nível de sua significação de base, na medida em que, nesse nível, algumas características de sua estrutura designativa e denotativa determinam, por si só, a impossibilidade de acesso a uma significação plena ${ }^{115}$.

A vagueza dos termos jurídicos, por sua vez, consiste em um grau de indeterminação pré-existente, vale dizer, que se dá diante de contextos não pensados pelo legislador. Com efeito, um termo é vago, em sentido amplo, nos casos onde não existe uma regra definida quanto a sua aplicação. É que, na prática, os critérios mediante os quais se pretende explicar o significado dos temos gerais da linguagem natural não permitem decidir, na totalidade dos casos, os limites precisos para sua denotação, devendo os usuários decidirem pragmaticamente se incluem ou não determinadas situações, objetos ou classes de termos dentro da denotação ${ }^{116}$. No caso da vagueza, pois, o predicado descritivo é de

112 Nesse sentido: "I owe this term to Mr. Kneale who suggested it to me as a translation of Porosität der Begriffe, a term coined by me in German" (WAISMANN, Friedrich. Verifiability. Analysis and metaphysics. Proceedings of the Aristotelian Society, Supplementary Volume XIX. London: Harrison and sons Ltda., 1945, p. 121, nota 2).

113 WARAT, Luis Alberto. O direito e sua linguagem. Com a colaboração de Leonel Severo Rocha. 2a versão. Porto Alegre: Sérgio Fabris, 1984, p. 68.

114 WARAT, Luis Alberto. O direito e sua linguagem. Com a colaboração de Leonel Severo Rocha. 2a versão. Porto Alegre: Sérgio Fabris, 1984, p. 76.

115 WARAT, Luis Alberto. O direito e sua linguagem. Com a colaboração de Leonel Severo Rocha. 2a versão. Porto Alegre: Sérgio Fabris, 1984, p. 76.

116 WARAT, Luis Alberto. O direito e sua linguagem. Com a colaboração de Leonel Severo Rocha. 2a versão. Porto Alegre: Sérgio Fabris, 1984, p. 76. 
referência imprecisa ${ }^{117}$, de modo que a redução da vagueza poderá se dar, no âmbito da norma jurídica, a partir de definições esclarecedoras realizando um processo através do qual se explica o grau em que as notas devem existir nos objetos para serem incluídos na classe ${ }^{118}$. Desse modo, tem-se como exemplo de vagueza a previsão do art. 5. o, LXXIV, da Constituição Federal, que prevê a assistência jurídica integral e gratuita aos que comprovarem a "insuficiência de recursos".

Note-se que o problema da vagueza se encaixa em juízo de "mais ou menos", o que implica uma questão da graduação, de quantidade. É o que acontece com o termo "calvo", na medida em que uma pessoa pode ser mais ou menos calva ${ }^{119}$. Diferentemente, os conceitos abertos, na dimensão do significado de base, em princípio, não apresentam problemas de indeterminação. $\mathrm{O}$ conceito carro, por exemplo, torna-se controverso diante de situações não previstas, vale dizer, diante de situações contextuais. Dito de outro modo, a indeterminação do conceito aberto poderá ser maior diante de certos contextos não previstos, ao passo que a indeterminação da vagueza poderá ser menor diante de contextos nos quais os elementos aclaratórios apresentam-se de forma mais específica.

Já a ambiguidade - constatada explicitamente pelo menos desde Thomas Hobbes, o qual, de certo modo, antecede em vários século o problema da indeterminação do Direito, dada a abertura dos termos linguísticos empregados pela lei ${ }^{120}$ - pode ligar-se a uma situação de homonímia ou de polissemia. A questão aqui reside no plano da incerteza significativa. Haverá homonímia quando um mesmo rótulo ou significante

117 WARAT, Luis Alberto. Introdução geral ao direito. Porto Alegre: Sérgio Fabris, 1994, p. 40.

118 WARAT, Luis Alberto. Introdução geral ao direito. Porto Alegre: Sérgio Fabris, 1994, p. 40.

119 PUPPO, Federico. Dalla vaghezza del linguaggio alla retorica forense: saggio di logica giuridica. Milano: Casa Editrice Dott. Antonio Milani, 2012, p. 21.

${ }^{120} \mathrm{Cf}$. Hobbes, The perspicuity consisteth not so much in the words of the law itself, as in a declaration of the causes and motives for which it was made. That is it that shows us the meaning of the legislator; and the meaning of the legislator known, the law is more easily understood by few than many words. For all words are subject to ambiguity; and therefore multiplication of words in the body of the law is multiplication of ambiguity: besides it seems to imply, by too much diligence, that whosoever can evade the words is without the compass of the law" (HOBBES, Thomas. Leviathan: Or the Matter, Forme and Power of a Commonwealth Ecclesiasticall and Civil. New York: Touchstone, 2008, p. 271). 
veicula propriedades designativas aplicáveis a âmbitos denotativos claramente diferenciáveis. E o caso da palavra manga, que pode designar uma fruta ou uma parte do vestuário ${ }^{121}$. Sob a forma de polissemia, a ambiguidade se refere aos casos em que um mesmo termo designa um conjunto de significativos designativos conectados metaforicamente: “assim, a palavra 'pesado' pode referir-se tanto a este livro como a uma tonelada de ferro, podendo também ser empregada para designar uma pessoa cansativa"122. Também aqui, muitas vezes, o contexto esclarecerá as dúvidas e não haverá ambiguidade. Daí que o problema da ambiguidade se encaixa em um problema de "concordância", pois de acordo com o contexto uma pena será uma caneta tinteiro ou uma pluma, sem que se possa dizer que a pena é mais ou menos caneta ou mais ou menos pluma ${ }^{123}$.

Como se vê, é possível trilhar dois caminhos de indeterminação do direito na perspectiva da linguagem: um que já se apresenta na dimensão do significado de base e que poderá ser reduzido na dimensão do significado contextual (vagueza e ambiguidade) e, outro, que se dará na dimensão do significado contextual e que poderá ser reduzido - mas nunca eliminado na dimensão do significado de base (textura aberta ou porosidade).

Com isso, pode dizer-se que a indeterminação é conatural ao direito. Ainda que se possa reduzir (mas não eliminar totalmente) a vagueza e a ambiguidade, afigura-se impossível afastar a porosidade. É que a referência à realidade é sempre mais complexa (nos elementos constitutivos e na relação entre eles) e diferente (no modo de manifestação e de determinação) do que é possível a qualquer enunciado lógico-linguístico comunicado por uma expressão verbal, de modo que o suporte fático presente no seu enunciado se revelará sempre incompleto (quanto ao seu conteúdo) e aberto (quanto ao âmbito e aos limites objetivos) na referência a realidade do seu cumprimento ${ }^{124}$.

121 WARAT, Luis Alberto. O direito e sua linguagem. Com a colaboração de Leonel Severo Rocha. 2a versão. Porto Alegre: Sérgio Fabris, 1984, p. 78.

122 WARAT, Luis Alberto. O direito e sua linguagem. Com a colaboração de Leonel Severo Rocha. 2a versão. Porto Alegre: Sérgio Fabris, 1984, p. 78.

${ }_{123}$ PUPPO, Federico. Dalla vaghezza del linguaggio alla retorica forense: saggio di logica giuridica. Milano: Casa Editrice Dott. Antonio Milani, 2012, p. 21.

124 CASTANHEIRA NEVES, António. O princípio da legalidade criminal. In: Digesta: escritos acerca do direito, do pensamento jurídico, da sua metodologia e outros. Volume 1ํ. Coimbra: Coimbra editora, 1995, p. 439. 
Não por acaso, no capítulo VII do seu "O Conceito de Direito", Herbert Hart busca evidenciar que problemas de indeterminação se fazem presentes nas duas principais estratégias utilizadas para a comunicação de padrões gerais de conduta antes que ocorram a sucessivas ocasiões em que devem ser aplicados, quais sejam, a lei e o precedente. Isso porque, diz ele, "não apenas no terreno das normas, mas em todos os caminhos da existência, há um limite inerente à natureza da linguagem, para a orientação que a linguagem geral pode oferecer" ${ }^{\prime 25}$. Portanto, segue Hart, qualquer que seja a estratégia escolhida para a transmissão de padrões de comportamento (lei ou precedente), "esses padrões, por muito facilmente que funcionem na grande massa de casos comuns se mostrarão imprecisos em algum ponto, quando sua aplicação for posta em dúvida; terão o que se tem chamado de textura aberta" ${ }^{126}$.

Com base em todos esses argumentos até aqui apresentados, fica claro que o problema da indeterminação da linguagem (e do Direito) não é um problema que se resolve no nível epistemológico. Não será um Código completo, precedentes ou súmulas que irão resolver por completo tal questão, pois estes também são veiculados na e pela linguagem. Sempre haverá indeterminação no Direito, razão pela qual é, no mínimo, inocente acreditar que epistemologicamente é possível sanar o problema da indeterminação, por exemplo, com "precedentes obrigatórios" ou com a outorga, para Tribunais Supremos, do papel de realizar uma espécie de "interpretação autêntica"127. A questão que se põe não é de epistemologia,

${ }^{125}$ HART, H. L. A. O conceito de Direito. Tradução de Antônio de Oliveira Sette Câmara. 1 ed. São Paulo: WMF Martins Fontes, 2012, p. 164.

${ }^{126}$ HART, H. L. A. O conceito de Direito. Tradução de Antônio de Oliveira Sette Câmara. 1 ed. São Paulo: WMF Martins Fontes, 2012, p. 166.

127 Valendo-se de conceitos formados no âmbito do common law, o discurso de Mello e Barroso soma-se a várias outras manifestações de uma parcela da doutrina brasileira que, a fim de, supostamente, promover isonomia na aplicação do Direito e segurança jurídica, defende que se confira força vinculante, obrigatória, às decisões dos Tribunais Superiores. A esses Tribunais, ou Cortes Supremas, segundo essa recente corrente doutrinária, reserva-se - nas palavras de Marinoni, Arenhart e Mitidiero, que são dos principais expoentes dessa tese "precedentalista" - "a função de atribuição de sentido ao Direto" (Cf. MARINONI, Luiz Guilherme. MITIDIERO, Daniel. ARENHART, Sérgio Cruz. O novo processo civil. São Paulo: Revista dos Tribunais, 2015, p. 105). Daí a afirmação, realizada pelos últimos autores citados, de que as Cortes Supremas existiriam para interpretar, ao passo que os juízes e Tribunais do andar de baixo existiriam para aplicar o Direito (leia-se, o Direito livre de imprecisões, na medida em que "aclarado" pelas Cortes Supremas. Para uma crítica a respeito da referida tese, ver 
mas antes, da própria natureza do Direito ou, se quisermos, é um problema de nível ontológico. Daí o acerto de Hart ao prescrever que "não devemos acalentar, nem mesmo como um ideal, a concepção de uma norma tão detalhada que a pergunta se ela se aplica ou não a um caso particular já tenha sempre sido respondida antecipadamente, sem nunca envolver, no momento de sua aplicação real, uma nova escolha entre alternativas abertas ${ }^{\prime \prime 28}$.

\section{CONCLUSÃo}

Verificou-se, no presente ensaio, que a questão da indeterminação da linguagem e, consequentemente, a indeterminação do Direito é algo inescapável, vale dizer, linguagem e indeterminação estão ligadas em um nível ontológico dado o seu aspecto pragmático. Nessa linha, viu-se que as posições filosóficas presas apenas aos níveis sintático e semântico não são capazes de cobrir toda a realidade, motivo que levou Wittgenstein a romper com o seu primeiro projeto, reelaborando aspectos essenciais na sua obra Investigações Filosóficas.

Com essas considerações de ordem filosófica, é possível que se coloque em xeque algumas posições da doutrina brasileira que pretendem resolver o problema da indeterminação do Direito com súmulas, enunciados, precedentes, etc. Parece ser um equívoco acreditar que exista algum mecanismo que seja capaz de operar aprioristicamente, eliminando o grau de indeterminação da linguagem, na medida em que o aspecto pragmático sempre se mostra como um elemento complicador de tais pretensões. Dito de outro modo, assim como os Códigos não conseguem abarcar o mundo de antemão, tampouco as súmulas, precedentes e enunciados também não possuem essa aptidão. Vale ressaltar, ainda, que insistir na ideia de que a doutrina do precedente poderia solucionar "problemas" interpretativos parece, inclusive, traduzir-se em passos traçados em direção contrária ao próprio common law, justamente de onde o stare decisis - e, portanto, a tentativa de apropriação brasileira - vem. Fiquemos com a advertência de Hart (autor

RAATZ, Igor. Precedentes à brasileira: uma autorização para "errar" por último?. Revista Consultor Jurídico. São Paulo: 03 out. 2016. Disponível em: [http://www.conjur.com.br/2016-out-03/igor-raatz-precedentes-autorizacao-errarultimo]. Acesso em: 18 mai. 2017.

128 HART, H. L. A. O conceito de Direito. Tradução de Antônio de Oliveira Sette Câmara. 1 ed. São Paulo: WMF Martins Fontes, 2012, p. 165-166. 
cuja obra, lembremos, insere-se justamente no âmbito do common law), no sentido de que "se o mundo no qual vivemos tivesse apenas um número finito de características, e estas, juntamente com todas as formas sob as quais podem se combinar, fossem conhecidas por nós, poderíamos então prever de antemão todas as possibilidades" ${ }^{129}$. Não há, pois, como antever - por mais minuciosa que seja a lei ou o precedente - todas as hipóteses de aplicação, de modo que, diante da faticidade que se apresenta nos novos casos, abre-se um novo horizonte de possibilidades. Essa abertura nos é imposta, diria Hart, "porque somos homens, e não deuses"130.

O ponto fundamental, em uma palavra final, é que precedentes, enunciados, teses e súmulas, assim como os Códigos, são forjados em linguagem e, portanto, também apresentarão problemas de porosidade, vagueza e ambiguidade. Como dito, trata-se de, antes da epistemologia, de uma questão de ontologia: a indeterminação faz parte da própria natureza do Direito, e qualquer tentativa de solução através de proposições "interpretativas", invariavelmente, falha em sua pretensão de totalidade significativa.

\section{REFERÊNCIAS}

ALCOFORADO, Paulo. Introdução da obra. In: FREGE, Gottlob. Lógica e filosofia da linguagem. Seleção, introdução e notas de Paulo Alcoforado. 2ª ed. São Paulo: Editora Universidade de São Paulo, 2009.

MELLO, Patrícia Perrone Campos; BARROSO, Luís Roberto.

Trabalhando com uma nova lógica: a ascensão dos precedentes no Direito brasileiro. Revista da AGU, v. 15, n. 3. Brasília: Editora Fórum, jul./set. 2016, pp. 9-52.

CARNAP, Rudolf. Autobiografía intelectual. Traducción de Carmen Castells. Barcelona: Editorial Paidós Ibérica, Universidad Autónoma de Barcelona, 1992.

${ }^{129}$ HART, H. L. A. O conceito de Direito. Tradução de Antônio de Oliveira Sette Câmara. 1 ed. São Paulo: WMF Martins Fontes, 2012, p. 165.

${ }^{130}$ HART, H. L. A. O conceito de Direito. Tradução de Antônio de Oliveira Sette Câmara. 1 ed. São Paulo: WMF Martins Fontes, 2012, p. 166. 
CARNAP, Rudolf. Introduction to semantics. Third printing. Cambridge - Massachusetts: Harvard University Press, 1948.

CARNAP, Rudolf. Logical syntax of language. London: Routlegde, 2000.

CARNAP, Rudolf. Significado e sinonímia nas linguagens naturais. In: SCHLICK, Moritz; CARNAP, Rudolf. Coletânea de textos. 3. ed. São Paulo, SP: Nova Cultural, 1988.

CASTANHEIRA NEVES, António. Metodologia jurídica: problemas fundamentais. Coimbra: Coimbra Editora, 1993.

CASTANHEIRA NEVES, António. O princípio da legalidade criminal. In: Digesta: escritos acerca do direito, do pensamento jurídico, da sua metodologia e outros. Volume 1ํ. Coimbra: Coimbra editora, 1995.

CORETH, Emerich. Questões fundamentais de hermenêutica. Tradução de Carlos Lopes de Matos. São Paulo: EPU, Ed. da Universidade de São Paulo, 1973.

CORREA, Cristina Rosineiri Gonçalves Lopes. A semântica de Frege e a dinâmica da verdade na psicanálise. Rev. Estud. Lacan, 2009.

D'OLIVEIRA, Armando. Wittgenstein - Vida e Obra. In: WITTGENSTEIN, Ludwig. Investigações filosóficas. Tradução: José Carlos Bruni. São Paulo: Nova Cultural, 1999.

FREGE, Gottlob. Lógica e filosofia da linguagem. Seleção, introdução e notas de Paulo Alcoforado. $2^{a}$ ed. São Paulo: Editora Universidade de São Paulo, 2009.

GADAMER, Hans-George. Hermenêutica em retrospectiva. A virada hermenêutica. Vol. II. Tradução de Marco Antônio Casanova. Petrópolis: Vozes, 2007, p. 16. 
GADAMER, Hans-Georg. Verdade e método. Tradução de Flávio Paulo Meurer; revisão da tradução de Enio Paulo Giachini. $7^{\text {a }}$ ed. Petrópolis, RJ: Vozes, Bragança Paulista, SP: Editora Universitária São Francisco, 2005.

GARRIDO, Manuel. Introducción: dos maneras de hacer filosofía.

CARNAP, Rudolf. Autobiografía intelectual. Traducción de Carmen Castells. Barcelona: Editorial Paidós Ibérica, Universidad Autónoma de Barcelona, 1992.

GUASTINI, Riccardo. Interpretare e argomentare. Milano: Dott. A. Giuffrè Editore, 2011.

HABERMAS, Jürgen. Pensamento pós-metafísico: estudos filosóficos. Rio de Janeiro: Tempo brasileiro, 1990.

HABERMAS, Jürgen. Verdade e justificação. Ensaios filosóficos. Tradução: Milton Camargo Mota. São Paulo: Loyola, 2004.

HART, Herbert L. A. Essays in jurisprudence and philosophy. Oxford: Clarendon Press, 1983.

HART, H. L. A. O conceito de Direito. Tradução de Antônio de Oliveira Sette Câmara. 1 ed. São Paulo: WMF Martins Fontes, 2012.

HOBBES, Thomas. Leviathan: Or the Matter, Forme and Power of a Commonwealth Ecclesiasticall and Civil. New York: Touchstone, 2008.

LAFONT, Cristina. The linguistic turn in hermeneutic philosophy. Translated by José Medina. Baskerville: Massachusetts Institute, 1999.

MARCONDES, Danilo. Filosofia analítica. Rio de Janeiro: Jorge Zahar, 2004. 
MARGUTTI PINTO, Paulo Roberto. O Tractatus de Wittgenstein como obra de iniciação. Filosofia Unisinos. vol. 5. n. 8. São Leopoldo: Editora Unisinos, 2004.

MARINONI, Luiz Guilherme. MITIDIERO, Daniel. ARENHART, Sérgio Cruz. O novo processo civil. São Paulo: Revista dos Tribunais, 2015.

OLIVEIRA, Manfredo Araújo de. Reviravolta linguístico-pragmática na filosofia contemporânea. São Paulo: Edições Loyola, 1996.

PUPPO, Federico. Dalla vaghezza del linguaggio alla retorica forense: saggio di logica giuridica. Milano: Casa Editrice Dott. Antonio Milani, 2012. (Org.) A. Kaufmann, W. Hassemer; tradução: Marcos Keel, Manuel Seca de Oliveira. Lisboa: Fundação Calouste Gulbekian, 2002.

SCHAUER, Frederick. Playing by the rules: a philosopical examination of rule-based decision-making in law and in life. New York: Oxford Claredon press, 2002.

SEGATTO, Antonio Ianni. Apresentação do texto "Sobre pensamento e linguagem" de Wilhelm Von Humboldt. In: Trans/form/ação. Revista de filosofia. Universidade Estadual Paulista/UNESP. v. 32, n. 1, 2009.

STEGMÜLLER, Wolfgang. A Filosofia Contemporânea: Introdução Crítica. 2ª . Rio de Janeiro Forense 2012.

STRECK, Lenio Luiz. Hermenêutica jurídica e(m) crise: uma exploração hermenêutica da construção do direito. $10^{a}$ edição revista, atualizada e ampliada. Porto Alegre: Livraria do Advogado, 2011.

STRECK, Lenio Luiz. Verdade e Consenso: constituição, hermenêutica e teorias discursivas. 6. ed. São Paulo: Saraiva, 2017.

TRAJAN, Tiago. A sintaxe lógica da linguagem de Rudolf Carnap: uma análise do princípio de tolerância e da noção de analiticidade. 
Dissertação de mestrado. Programa de Pós-Graduação em Filosofia do Departamento de Filosofia da Faculdade de Filosofia, Letras e Ciências Humanas da Universidade de São Paulo - USP. São Paulo: USP, 2005.

VALLAURI, Luigi Lombardi. Norme vaghe e teoria generale del diritto. Ars interpretandi. Annuario di ermeneutica giuridica. L'intenzione nell'interpretazione. Padova: CEDAM.

WAISMANN, Friedrich. Verifiability. Analysis and metaphysics.

Proceedings of the Aristotelian Society, Supplementary Volume XIX. London: Harrison and sons Ltda., 1945.

WARAT, Luis Alberto. Introdução geral ao direito. Porto Alegre: Sérgio Fabris, 1994.

WARAT, Luis Alberto. O direito e sua linguagem. Com a colaboração de Leonel Severo Rocha. 2a versão. Porto Alegre: Sérgio Fabris, 1984.

WITTGENSTEIN, Ludwig. Investigações filosóficas. Tradução: José Carlos Bruni. São Paulo: Nova Cultural, 1999.

WITTGENSTEIN, Ludwig. Tractatus logico-philosophicus. Tradução e apresentação de José Arthur Giannotti. São Paulo: Companhia editora nacional - Editora da universidade de São Paulo, 1968.

A FILOSOFIA DA LINGUAGEM ORDINÁRIA E A (INESCAPÁVEL) INDETERMINAÇÃO DO DIREITO

ORDINARY LANGUAGE PHILOSOPHY AND THE (UNAVOIDABLE) LEGAL INDETERMINACY

Submetido em: 2017-11-06 Aceito em: 2018-06-22 